\title{
Professional/Career Orientation, Awareness, And Their Relationship To Locus Of Control
}

Nourah A. Algadheeb, Princess Nourah Bint Abdulrahman University, Saudi Arabia

\begin{abstract}
This study aimed at exploring the differences in professional/career orientation and awareness while considering a number of variables including locus of control, academic specialization and school backwardness. Several measures were used to achieve the study's goals. The first two, a professional/career orientation measure and a professional/career awareness measure, were designed by the researcher, whereas the third measure was Rotter's locus of control scale. Prior to the study, the stability and validity of these tools were verified on 166 female student participants chosen from Princess Nourah Bint Abdulrahman University (PNU). The results indicated the presence of differences with respect to the electronic orientation of female students according to Rotter's external locus of control measure. The study also confirmed that there were differences in the professional awareness variable in favor of female students who exhibited an external locus of control, whereas no differences were noted in the professional awareness of female students with different professional orientations. The findings also showed differences in scientific and electronic orientations among students with different specializations, in favor of the female students enrolled in the Department of Computer Science and Information Technology, whereas no differences were noted in professional/career awareness for the academic specialization variable. No differences were noted in the professional orientations and awareness among female students who demonstrated school backwardness and those who did not. The results were interpreted in light of the theoretical frameworks and cultural contexts of the sample. The results of the study were also linked to previous results.
\end{abstract}

Keywords: Professional Orientation; Professional/Career Awareness; Locus Of Control; Community College

\section{INTRODUCTION}

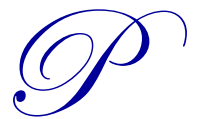

rofessional orientations are the trends and behaviors that express an individual's desire to pursue or apply oneself to a specific occupation and, together, these orientations affect the individual's decision-making process with respect to occupational choice (Gerber, Wittekind, Grote, \& Staffelbach, 2009).

Professional orientations are important insofar as they address an individual's specific abilities. However, recognizing or identifying an individual's interests and strengths is considered one of the more difficult and complicated tasks that teachers and organizational leaders face as they strive to guide students and employees to pursue appropriate careers (Ari, Vatansever, \& Uzun, 2009).

Professional orientation is thus considered one of the determinants that guides the personal choices that individuals make. Furthermore, it is perceived as an indicator of the degree of democracy and individual freedom one has in determining his or her professional career and, ultimately, his or her future (Lami \& Mile, 2013).

Special programs help in developing professional orientations in educational environments by providing students with the appropriate support and by helping them to recognize their physical, cognitive and personal traits. 
These programs also assist students in finding careers that are in harmony with these traits and in linking students' skills with workplace requirements (Milloshi, 2013).

Professional orientation should begin in the school environment, as it increases student awareness of the varied natures of different jobs and helps to identify the jobs that are most suitable for the individual student. Such orientation is considered even more important with respect to the social environments associated with various careers. Institutions of higher education are responsible for developing students' specific skills, such as being aligned with the chosen career workplace requirements. This continuity creates a connection between the actual framework of the study and the expectations of the external labor market (Milloshi, 2013).

As a result of this important role played by university environments, institutions of higher education should provide programs that aim at constructing students' professional orientations and developing their administrative skills (Palade \& Constantin, 2012).

The results of the previous studies confirmed the importance of offering programs aimed at developing professional orientations in higher educational institutions, as these programs have been found to change students' professional orientations and improve the competencies required for various professional cultures and to enhance individual growth (Nikolaou, 2008).

Therefore, it can be concluded that a failure to develop students' professional orientations may result in a lack of student awareness of the nature of various jobs available in their societies and that this lack of awareness results in confusion and, hence, a lack of focus on specific objectives among students.

In McKnight's (2009) study of students in their final year of high school, it is determined that the failure to introduce and develop professional orientations during the early years in school environments has resulted in delayed planning on the part of students with respect to careers. When students were not introduced to professional orientations at an early age, they could not effectively define future jobs and careers. It was also found that insufficient financial resources were allocated to activities and training programs aimed at increasing student awareness with respect to professional orientations.

Professional orientations are established according to a number of psychological theories, such as a theory on personality and occupations (Holland, 1959) - a theory based on the premise that professional orientation is a personality trait. In other words, when an individual describes his or her professional orientation, he or she is, in fact, describing his or her character; thus, persons may be classified according to one of six personality types: realistic, investigative, technical, social, adventurous, and traditional.

Holland (1959), (as cited in El-Khatieb, 2005) contends that these personality types or orientations are the product of interactions among several factors, including genetics, upbringing and personal and social experiences. Such factors and interactions cause a person to prefer certain activities and not others. These preferences then develop into orientations, which then lead to personal competences and choices that cause an individual to think and behave in a definitive way. For example, a social person is more inclined to work in social occupations, such as education or human services.

The factors that influence professional orientation are myriad, and these factors differ according to the individual and to the varied social and economic pressures, which may cause individuals to select one job or career over another.

The results of another study (Nagy, 2008) further identify certain factors that influence the professional orientations of students. Among these factors are the individual's beliefs regarding the social nature of their future profession; the individual's personal characteristics, abilities and skills; the professional awareness and knowledge that the student acquires from the university; and the future expectations of the profession.

However, the findings of another study (Karpenko, 2013) suggest that the social status of the occupation within the society is one of the main factors affecting the professional orientations of the medical students. 
In another study, it is the students' degree of effectiveness with respect to specific professional skills and their motivation toward a definite professional activity that influences the students' professional orientations (Kara, 2013).

There are many studies that have investigated the relationship between professional orientation and specific variables, such as multiple intelligences, personality traits, academic achievement, academic specialization, creative abilities, and cognitive style, in samples of high school and university students (El-Ewies, 2007; El-Khatieb, 2005; Kelly \& Kneipp, 2004; Mekdad \& Hussein, 2011; Moussa, 2003).

A professional orientation towards a specific job involves many factors, including personal motivation and a personal desire to pursue the job which, in turn, entail gaining an in-depth understanding of what the job requires and adopting the values and principles inherent to the job. The individual who has reached this level of understanding with respect to a specific job or career has acquired a high degree of professional awareness that incorporates a system of images, beliefs, ideas, feelings and approaches constituted within the individual (Oleg et al., 2011).

In this sense, professional awareness is a variable that attracts many researchers from both the educational and the regulatory fields due to its potential to improve the individual's level of knowledge and skills in a way that positively impact professional development (Wiroterat, 2013).

Professional awareness is considered a complicated factor insofar as it is the result of various interactions among numerous factors, such as professional knowledge, professional perfectionism, emotional aspects related to the profession, professional beliefs and professional preparation. Furthermore, there are many other factors that affect an individual's level of professional awareness, such as the individual's degree of motivation, the nature of the work environment and the extent of transparency and clarity regarding the profession ( $\mathrm{Li}, 2012)$.

Accordingly, professional orientation and professional awareness are closely interdependent insofar as one's personal characteristics, desires and efforts, in addition to one's personal view of the world being expressed through the psychological concept known as locus of control.

The locus of control concept, one classical concept in psychology, was introduced in 1966 by Julian Rotter when he used an assessment tool that enabled researchers to evaluate the general expectations of individuals in relation to their loci of control (Henderson, 2009).

Locus of control is seen as the individual's belief in his or her ability to govern or direct the incidents and experiences that affect his or her life. The individual who perceives that external factors control his or her decisions and personal life and who believes that he or she has no influence on these external factors exhibits an external locus of control (Zhang, Liu, Jiang, Wu, \& Tian, 2014).

Locus of control is a relatively stable personality trait. That is, the person either believes that he or she is the only one who is responsible for his or her successes or failures, or the individual attributes his or her success or failure to external factors. Persons with an internal locus of control attribute their success or failure in life to their own abilities and efforts, whereas persons with an external locus of control think that their success or failure is the result of outside factors, such as luck or a poor instructional environment (Parameswari \& Shamala, 2012).

Nuga (2013) contends that the definition of locus of control further incorporates the different ways in which individuals recognize reward and punishment mechanisms. This same study suggests that locus of control includes the individual's view about possible future events; that is, whether future events are the results of one's own actions or the results of external factors and powers that are beyond the control of the individual.

There are many factors that contribute to the formation of one's locus of control, one of which is gender. The findings of many studies suggest that although male students exhibit high levels of internal locus of control, most female students exhibit high levels of external locus of control (Aliouby, 2006; Badr, 2006; El-Ahmady, 2007; Ibrahim, 2005; Zaidi \& Mohsin, 2011; Serin, Serin, \& Şahin, 2010). Conversely, there are studies that find the 
opposite; namely, that male students exhibit greater external locus of control, whereas female students have greater levels of internal locus of control (Cetinkalp, 2010; Sarıçam, Duran, \& Çardak, 2012).

According to a study by Serin and others (Serin et al., 2010), the economic level may play a role in the formation of one's locus of control. Their study found that university students from advantaged economic backgrounds have higher levels of internal locus of control compared to those from lower economic backgrounds. A study by Stocks and others (Stocks, April, \& Lynton, 2012) confirmed that the social culture also contributes to the forming of one's locus of control. For example, it is quite common for the people of China to possess an external locus of control, which is very common among its people, whereas there are significant differences among the people of South Africa with respect to locus of control because some display a strong external locus of control and others possess a strong internal locus of control.

The current study also asserts that social upbringing significantly affects one's locus of control. A social upbringing that supports and encourages self-confidence, independence, initiation, and reflection/meditation regarding the experiences of success and failure among children supports and promotes the development of an internal locus of control, whereas a social upbringing that supports and promotes an external locus of control is one that encourages dependency and a reliance on others and attributes success and failure to external factors.

Although locus of control is not a new concept and because it is one that has been thoroughly investigated, it is relevant and worthy of further study because of its relation to many variables related to the student sample in this study. In fact, there are many recent studies that have explored the relations among locus of control, cognitive variables and individual factors.

Many of these studies have found a positive relationship between internal locus of control and certain cognitive variables, such as academic achievement, learning, performance improvement, cognitive beliefs, reading comprehension, as well as independence with respect to the cognitive domain (Bernardi, 2013; El-Harby, 2006; ElHekmy, 2004; El-Mazroa, 2008; Kalantarkousheh, Mohagheghi, \& Hosseini, 2013; Kutanis, Mesci, \& Övdür, 2011; Nejabati, 2014; Nejati, Abedi, Aghaei, \& Mohammadi, 2012; Nuga, 2013; Terzi, Çetin, \& Eser, 2012).

Other studies have found positive relationships between internal locus of control and numerous personal characteristics, including self-esteem, self-confidence, leadership, self-efficacy, self-concept, psychological health, social control and social responsibility. Still others have found positive relationships between external locus of control and a number of health and behavioral factors, such as pressure and tension, psychic unity, test anxiety, aggression, irrational ideas, sleep disorders, levels of physical activity and smoking (Aliouby, 2006; AlMohammdy, 2004; Ayodele, 2013; El-Shagrawy, 2005; Helmer, Krämer, \& Mikolajczyk, 2012; Klyoopi, 2009; Naseri \& Ghabanchi, 2014; Popova, 2012; Rastegar \& Heidari, 2013; Saadat, Ghasemzadeh, Karami, \& Soleimani, 2011; Uçar \& Duy, 2013; Wallace, Barry, Zeigler-Hill, \& Green, 2012).

Professional orientation, professional awareness, and locus of control also represent important variables because they influence students in their academic choices which, in turn, affect the jobs/careers that will later be available to them. The more control the student has over his or her professional choice, the easier it is to determine his or her goals and the better able the student will be to achieve academic and professional success.

Because of the large number of students applying for undergraduate study and the weaknesses in student achievement of some applicants, universities cannot accept all applicants. Therefore, only those students who meet the established criteria for acceptance are admitted to the universities. Those who do not meet the criteria apply to other institutions according to their interests, whereas those students with low academic scores often attend the community colleges, which absorb such students and provide them with an alternative rather than leaving them without any possibility for academic and professional preparation? 


\section{THE STUDY PROBLEM}

The history of community colleges dates back to the early twentieth century. Although some researchers argue that community colleges were established as recently as 1940, their origins, according to most, are founded in what were once known as junior colleges (Hull, 2004).

As such, these colleges appeared for the first time as extensions of the secondary schools and were referred to by some as grades thirteen and fourteen. To confirm this notion, some of these institutions were operated under the patronage of the public school boards. Now, however, these community colleges are independent educational institutions (Hill, 2007).

Saudi Arabia followed a consistent policy and community colleges began to appear in the late 1990s. Currently, there are more than 40 community colleges spread throughout the kingdom. The primary goals of establishing these colleges inside the Kingdom are to meet the rapidly increasing needs of the labor market and to reduce the burden and pressures that colleges and universities are facing due to the increasing number of female students enrolled. Because the community colleges are being supervised by the Saudi universities, the Ministry of Higher Education assumes responsibility for supporting these colleges in coordination with the universities with which the colleges are affiliated (Al-Murabit, 2012).

Community colleges are public colleges that offer two-year programs of study, after which the learner is entitled to receive a certificate, a diploma or a fellowship, providing all criteria have been fulfilled (Scolari, 2012).

Community colleges are regional educational institutions that are intended to provide educational programs that meet the needs of the community in which they exist. Community colleges also include a number of curricula that parallel what is taught in university environments, thus allowing female students to find employment opportunities or improve or upgrade their skills. Accordingly, these colleges are based on specific policies, such as open admissions and reduced fees (Austin, 2008; Montoya, 2007; Scaggs, 2004; Vickers, 2007).

The roles of community colleges can be divided into four categories: 1) to prepare female students to advance to other educational institutions, 2) to provide technical and vocational training, 3) to reform education, and 4) to enrich the life of the student. The first purpose of the community college is to help female students transition to a more advanced educational institution by providing them with the basic skills and knowledge needed for success at four-year universities. The second role involves offering the vocational and technical education and skills needed by female students to enter the labor market. The third role is that of educational reform. As such, the community college is expected to improve the academic performance levels of female students who perform poorly with respect to basic skills in reading, writing, math and foreign language as a second language. Finally, it is intended that the community college will facilitate female students in fulfilling their personal interests and thereby enrich the quality of their lives (Furchtgott-Roth, Jacobson, \& Mokher, 2009).

The American Association of Community Colleges noted that community colleges play an important role in the society. For example, the community college is the entrance point to post-secondary education for $45 \%$ of newly registered students in higher education institutions in the United States. Furthermore, it is the entry point for $46 \%$ of all newly registered female university students in the United States (Lovell, 2007).

A recent field survey was conducted by the U.S. Department of Education to identify the degree to which community colleges succeeded in fulfilling the four roles. The results indicated that community colleges have high rates of student enrollment, especially with respect to adult female students. Furthermore, community colleges have successfully reduced tuition costs per student, they provide reform services, and they improve the academic performance levels of female students (Crawford \& Jervis, 2011).

The results of a study by Thomas (2003) confirmed the presence of a positive correlation between community colleges and economic growth, showing that community colleges play a prominent role in evaluating the economic needs of a community by communicating with the external world, by identifying the needs of both the 
industrial and business sectors, and by providing ongoing training of the workforce. In other words, all these factors positively support the economic growth processes of communities.

Focusing on this area brings attention to the lack of research that has been conducted in the field of twoyear community colleges, which does not compare to the amount of research conducted with respect to four year colleges. This lack of research has prompted many to conclude that community colleges do not receive adequate attention from researchers, perhaps because of the disparity between the colleges, whether with respect to the origination or the specialization of the community college, which are significantly different from those of four-year colleges and universities because these are easily classified either at the level of origination or at the level of specialization (Manias, 2007).

The lack of research may have prevented the identification of the most salient problems experienced by community colleges. Herein, it is necessary to emphasize the importance of the existence of several rules, policies and administrative directives that guarantee that the programs offered in these colleges are coordinated and consistent with current standards and that the programs actually contribute to the transition of female students from the community college to a four-year university (Hill, 2007).

Furthermore, there have been some criticisms directed at the community colleges with regard to the fact that the graduates from these institutions are older and less academically qualified than the female graduates of fouryear universities. It has also been determined that the dropout rates of community colleges are higher than those of four-year institutions (Powell, 2004).

With respect to the environment of Saudi Arabia, one of the most important problems faced by the community colleges was the relatively low view held by the community because many believe that these colleges are not of the same quality as four-year institutions and thus, they are of a lower status than universities. An additional problem is the admission policies of these colleges as they are forced to accept female students with lower levels of academic performance. This is evident by the fact that most of the graduates of community colleges in Saudi Arabia find it difficult to continue their academic studies in Saudi's public universities. Accordingly, the morale of the female students in community college environments is low, the dropout rates are high, and there is a general state of discontentment and dissatisfaction compared to the female students in four-year colleges (AlMurabit, 2012).

With respect to problems regarding general practices and the low level of performance, there are strategies that can be implemented to improve the performance levels of community college students. For example, the colleges can offer mentoring programs that guide female students to choose fields that are consistent with their talents and abilities. The colleges can also establish learning communities, focus on developmental learning that is aimed toward improving the level of academic capabilities of female students, and actively engage in reform processes that include all community college levels (Bailey \& Alfonso, 2005).

The researcher concurs with the findings of previous studies regarding the problems currently plaguing the community colleges, including the negative perceptions of female students and their parents' perceptions that these colleges are of a lower status and are not equal to four-year universities. The researcher further recognizes the intense pressure faced by university administrations and faculties to accept female transfer students from community colleges so the students can earn a bachelor's degree. This pressure is prompting university management and colleges to change the current transfer policy which requires students not able to transfer until completing their entire two-year program to allowing students to transfer after only a single semester or one academic year, upon the condition that they meet high academic standards. One of the important objectives that the community college seeks to achieve at Princess Nourah Bint Abdulrahman University is to provide a transition program that enables students to complete as much of their undergraduate studies as possible, or at least to provide female students with the skills and knowledge necessary to transfer to colleges that do not require strict acceptance criteria, such as colleges of education, the arts, and social sciences. Such transition programs would also provide students with assistance in establishing career goals and in making career decisions. 
A close examination into the nature of the problems confronting community colleges finds that part of the problem is concentrated on the quality of the female students themselves. Typically, female students have poor academic performances. For example, a community college at Princess Nourah Bint Abdulrahman University accepts female students whose grade point averages are as low as 2.75 out of 5.0 and at-risk female students who fail in their preparatory year. While the community colleges admit female students who wish to study at a community college, their numbers are limited.

Thus, one of the most important points of the research is the psychological study of community college female students. However, the majority of the extant studies on community colleges tend to focus on the administrative and organizational aspects of the leaders and presidents of the institutions (Bradley, 2009; Carter, 2009; Davis, 2009; Fisher, 2009; Gascon-Brewton, 2011; Parker, 2011; Ware, 2011; Wyatt, 2009; Weltsch, 2009; Yarber, 2006).

The researcher did not find any psychological studies that focused on female community college students. Therefore, by referencing one of the roles played by community colleges - vocational rehabilitation for the labor market -it is deemed appropriate to examine certain professional variables, such as professional orientation and professional awareness, and their relations to basic personal variables, such as locus of control. The results support the severe objections expressed by female students when they are assigned to a community college while justifying their objections to having to study the college's established disciplines, which is based scientifically on professional orientation. Furthermore, the study identifies a lack of conviction regarding vocational rehabilitation and employment after two academic years in that it reflects weak professional awareness and a perception of inferiority held by female students and their parents towards the college. This negative perception may be, in part, due to society's general attitude and the intervention of the parents themselves, as they want their daughters to attend fouryear colleges. Such interference may reflect, to some degree, an external locus of control.

These observations are the researcher's conclusions and, as such, they require scientific exploration. Accordingly, the following questions are proposed and examined herein. Are there statistically significant differences between the mean scores of female community college students with respect to professional orientation due to locus of control (internal - external)?

1. Are there statistically significant differences between the mean scores of female community college students with respect to professional awareness based on locus of control (internal - external)?

2. Are there statistically significant differences between the mean scores of female community college students with respect to professional awareness based on differences in professional orientation?

3. Are there statistically significant differences between the mean scores of female community college students with respect to professional orientation based on differences in academic specialization?

4. Are there statistically significant differences between the mean scores of female community college students with respect to professional awareness based on differences in academic specialization?

5. Are there statistically significant differences between the mean scores of female community college students with respect to professional orientation based on differences in stumbling academically (at risk not at risk)?

6. Are there statistically significant differences between the mean scores of female community college students with respect to professional awareness based on differences in stumbling academically (at risk not at risk)?

\section{The Study Aim}

The present study aims at identify differences in professional orientation and professional awareness based on locus of control (external - internal), on areas of specialization (business administration, office management, sales and marketing, computer science and information technology), and on stumbling status (at risk - not at risk). 


\section{Study Importance}

\section{Theoretical Importance}

1. This study contributes to the field of psychological research related to community college students. There is a dearth of research, especially in Arabic studies, focusing on community college students. Understanding the role played by community colleges, however, has become extremely relevant because these institutions are becoming increasingly involved in preparing students for the labor market and in helping them transfer from the community college to four-year institutions so they can earn their degrees.

2. This study is consistent with modern trends and practices in that it focuses on professional variables and needs to be related to the labor market. As such, the study examines two variables with a professional nature; namely, professional orientation and professional awareness.

3. This study interprets and discusses professional orientation and professional awareness from the perspective of a basic psychological trait - locus of control.

\section{Practical Importance}

1. The study results benefit officials and decision-makers at the community college level as they assist students in the registration process across various disciplines according to the students' professional orientations. This contributes to the development of educational programs designed to identify professional orientations which, in turn, will lead to the development of professional awareness.

2. The study provides two measures, both of which have been psychometrically verified - the professional orientation scale and the professional awareness scale.

\section{Definition Of The Study}

\section{Professional/Career Orientations}

Professional orientation is defined as one's attitude toward certain professional interests or jobs (Ryynänen, 2001, p. 8).

Professional orientation can also be defined as "the process used in describing the nature of a person's orientation and attitudes towards his future career, which can be formulated through information gained through individual education and counseling."

The researcher herein procedurally defines professional orientation as the degree mean obtained by female students with respect to each orientation on the professional orientation scale.

\section{Professional/Career Awareness}

It is the system composed of images, beliefs, thought, feelings, and attitudes which are inherent in the individual and directed towards a specific profession. (Oleg et al., 2011, p. 18)

The researcher procedurally defines professional awareness as "the total degree on the professional awareness measure."

\section{Locus Of Control}

Locus of control "...is believing in the causes of results which have been achieved, as whether these results were achieved by actions and real performance levels and one's personal characteristics, or they were achieved only because of fate or luck or coincidence that one has nothing to do about it, and through such other things which are out of control and unpredictable" (Wallace et al., 2012, p. 213).

The researcher procedurally defines locus of control as "the total degree of the locus of control measure." 


\section{Community College}

Community college "...is one of the post-secondary education institutions that helps in providing a lot of technical and academic services in the way that helps to get accredited technology certificate or fellowship degrees in the field of applied sciences or arts" (Luna, 2007, p. 15).

The researcher procedurally defines community college as one affiliated with the Princess Nourah Bint Abdulrahman University, which was established in 2002. The community college consists of two educational divisions - a computer and information technology department and an administrative sciences department. It offers a two-year course of study and the student is awarded a participant's degree upon successful completion.

\section{Study Limitations}

The current study is defined according to the variables-viz., professional orientation, professional awareness and locus of control-and the academic specializations - computer sciences and information technology and administrative sciences. The study is further defined according to its sample-female community college students at Princess Nourah Bint Abdulrahman University. Finally, it is defined according to its tools - the professional orientation and professional awareness measures (both of which were prepared by the researcher) and Rotter's measure of locus of control.

\section{Study Hypotheses}

1. For the study sample, there are no statistically significant differences between the medians with respect to professional orientations according to the differences in locus of control (internal - external).

2. For the study sample, there are no statistically significant differences between the medians with respect to professional awareness according to the differences in locus of control (internal - external).

3. For the study sample, there are no statistically significant differences between the medians with respect to professional awareness according to the differences in professional orientations.

4. For the study sample, there are no statistically significant differences between the medians with respect to professional orientations according to the differences in academic specialization.

5. For the study sample, there are no statistically significant differences between the medians with respect to professional awareness according to the differences in academic specialization.

6. For the study sample, there are no statistically significant differences between the medians with respect to professional tendencies according to the differences in stumbling academically (not at risk - at risk).

7. For the study sample, there are no statistically significant differences between the medians with respect to professional awareness according to the differences in stumbling academically (not at risk - at risk).

\section{Study Procedures}

\section{Study Community}

All the participants were second-level female students enrolled in the community college at Princess Nourah Bint Abdulrahman University. There were 470 students from two of the college's divisions: administrative sciences and computer and information technology.

Study Sample

The study sample consisted of 166 students from the second level of a community college, because this level was sufficient to ensure that the students had college experience and had engaged in college studies. Students in the sample were members of the college's first graduating class. Table 1 presents a sample distribution according to the study variables - specialty, academic stumbling, locus of control, and professional tendencies. 
Table 1: Sample Description According To Study Variables

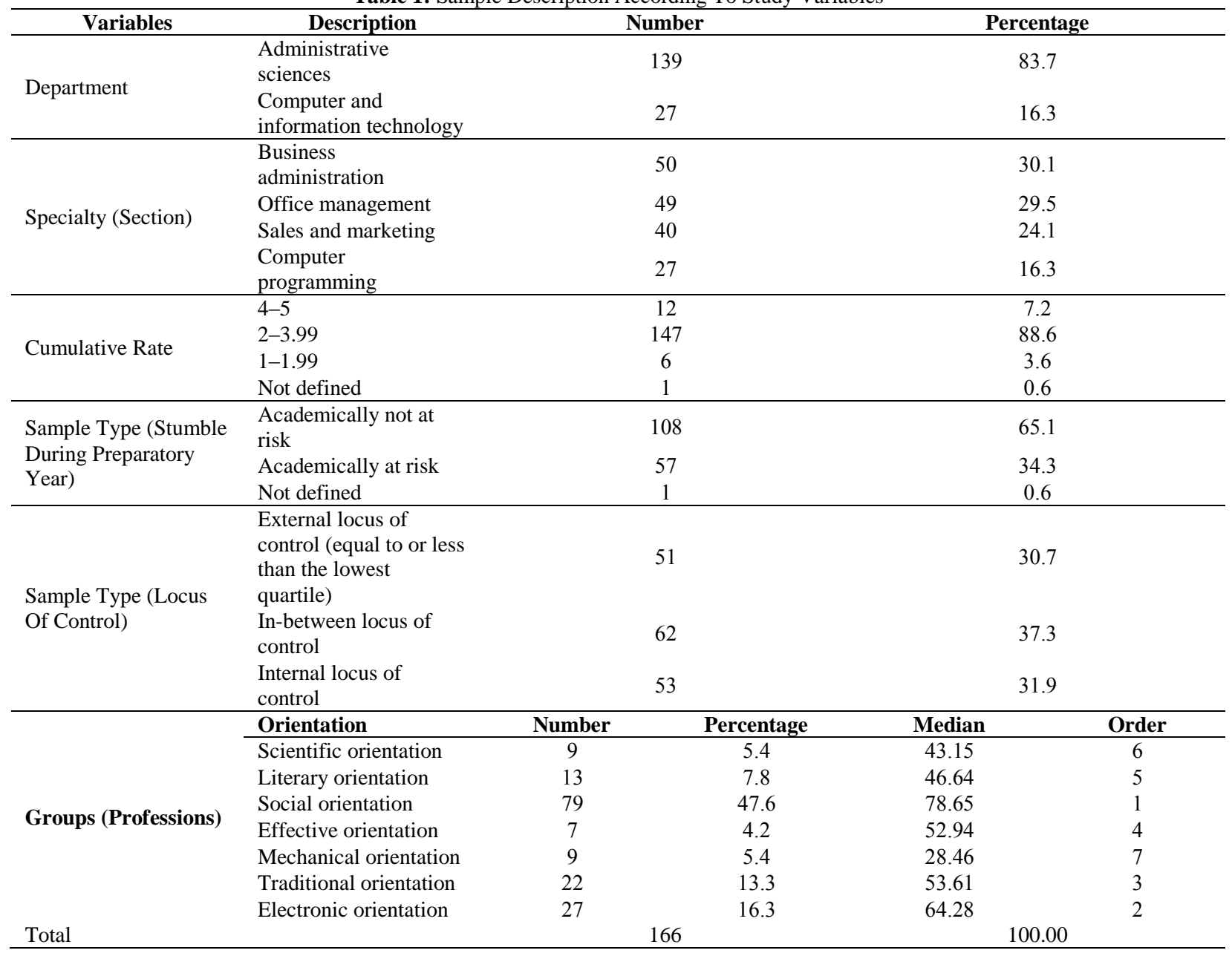

Table 1 presents sample characteristics for certain variables with respect to academic specialization. For example, the percentage of female students in administrative sciences was $83.7 \%$, whereas the percentage of female students in computer sciences and information technology was only 16.3\%. This large discrepancy exists because the administrative sciences department accepts students from both literary and scientific divisions, whereas the computer and information technology department only accepts students from the scientific division. The reason for the stricter admission requirements is that most of the students who transferred from the community college were studying in the literary division. Furthermore, some students contend that the computer/technology department is more difficult than the literary department.

With respect to areas of study, the greatest percentage (30.1\%) of the students was enrolled in the business administration section (30.1\%), followed by office management with $29.5 \%$, and sales and marketing with $24.1 \%$. The higher percentage of students enrolled in business administration is a consequence of this area of study expanded through the business and administration college, which offers a bachelor's degree. The other areas of study have no specialty extensions. Furthermore, the reason for the lower number of students in the sales and marketing division is due to the negative social status associated with this field of study as students equate the field to that of sales persons or sales representatives.

Table 1 presents the sample data with respect to cumulative rates/grades. The greatest percentage of students $(88.6 \%)$ was reported for those with scores between 2.0 and 3.99. The second highest percentage (7.2\%) was reported for those with grades/scores between 4.0 and 5.0. Only 3.6\% of the students reported scores between 1.0 and 1.99 , whereas $0.7 \%$ did not report their scores. The reason for the extraordinarily high percentage of students 
in the 2.0 to 3.99 range is because they transferred to the community college with scores of 2.75 or below. The increase in scores that exceed this range is due to the students' efforts to raise their scores, as doing so is one of the requirements to transfer from the community college to a four-year institution.

A sample description in terms of stumbling academically is also presented in Table 1. As evidenced from the data, the largest percentage of not-at-risk students in the preparatory year was $65.1 \%$. The percentage of at-risk students was $34.3 \%$ and the percentage of students who did not define their stumbling risk was $0.7 \%$. The reason for the large percentage of not-at-risk students is due to their desire to pass.

Table 1 presents a sample description in terms of locus of control. The largest percentage (37.3\%) exhibited loci of control somewhere between internal and external. The percentages for the two were quite close - the internal locus of control was $31.9 \%$ and the external locus of control was $30.7 \%$. The reason for the predominance of locus of control falling between internal and external was due to the age factor of the study sample and the academic stage of the students as they are at a point where they are focused on themselves and on the reasons for their success and failure. This is especially relevant if a student studied arduously against her will when being forced to attend the community college. The external locus of control, however, still influences a student's personality due to cultural factors of the community, social upbringing and, to some extent, gender, according to some studies, which are all effects of the locus of control.

Table 1 also shows sample characteristics with respect to professional orientation. Professional orientation percentages for the study sample were social orientation with a median of 78.65 , electronic orientation with a median of 46.28 , traditional orientation with a median of 53.61, affective orientation with a median of 52.49, literary orientation with a median of 46.64 , scientific orientation with a median of 43.15 , and mechanical orientation with a median of 28.46. These results are partly explained by the fact that a large percentage of students who transferred to the community college were from literary divisions and the professions that best fit this division are social professions such as teaching, special education, social services, or desk work. Electronic orientation ranked second partly because of the current age orientation toward technology, which includes younger individuals. This group represents those who use technology and more easily adapt to it. However, scientific and technical orientations ranked in the bottom two - a fact that may be attributable to the large number of students specializing in literary domains, whereas the correlation between scientific specialization and academic excellence is strong. Accordingly, it can be concluded that the sample is characterized by students at the mean rate or lower. Furthermore, the decrease in technical orientation among the study sample may be because the study sample was comprised of all females, while technical orientation is usually regarded as a male-dominated field, insofar as it often requires physical exertion.

\section{Study Tools}

\section{Professional Orientation Measure}

This measure was designed by the researcher using the concept of dimension "orientations" from the Holland measure. The researcher added a new dimension - electronic orientation - to better fit the requirements of the environment. Every orientation consisted of a number of activities from which the student chose according to her personal orientations. The measure consisted of seven orientations.

1. Scientific orientation (exploratory): eight activities

2. Literary orientation (art): seven activities

3. Social orientation: nine activities

4. $\quad$ Affective orientation (adventurous): nine activities

5. Mechanical orientations (realism): eight activities

6. Traditional orientation (office): five activities

7. Electronic orientation: ten activities

Every orientation was evaluated in a consistent manner and student orientation was considered to be high if the score exceeded the average. There was no total degree for the measure. 
The validity and reliability of the scale for the current study sample were verified, as illustrated by the following procedures.

\section{The Validity And Reliability Professional Orientation Scale}

The validity and reliability of the professional orientation scale were verified using a sample of female students. Validity was measured based on internal consistency by calculating the correlation coefficient for items on the professional orientation scale according to the total degree of the professional orientation dimension. Reliability was ascertained using Cronbach's alpha. Table 2 presents the results for internal consistency and reliability.

Table 2: Validity And Reliability Results Of The Professional Orientation Scale

\begin{tabular}{|c|c|c|c|c|c|c|c|}
\hline Dimension & $\begin{array}{l}\text { Correlation } \\
\text { Coefficients }\end{array}$ & No. & $\begin{array}{l}\text { Correlation } \\
\text { Coefficients }\end{array}$ & No. & $\begin{array}{l}\text { Correlation } \\
\text { Coefficients }\end{array}$ & No. & $\begin{array}{l}\text { Reliablility } \\
\text { Coefficient }\end{array}$ \\
\hline \multirow{3}{*}{$\begin{array}{l}\text { Scientific } \\
\text { Orientation }\end{array}$} & $* * 0.3477$ & 7 & $* * 0.6510$ & 4 & $* * 0.4746$ & 1 & \multirow{3}{*}{0.65} \\
\hline & $* * 05674$ & 8 & $* * 0.6248$ & 5 & $* * 0.6419$ & 2 & \\
\hline & $0.50 / 4$ & 8 & $* * 0.3597$ & 6 & $* * 0.6038$ & 3 & \\
\hline \multirow{3}{*}{$\begin{array}{l}\text { Literary } \\
\text { Orientation }\end{array}$} & & & $* * 0.6340$ & 4 & $* * 0.4273$ & 1 & \multirow{3}{*}{0.61} \\
\hline & $* * 0.6353$ & 7 & $* * 0.5612$ & 5 & $* * 0.4260$ & 2 & \\
\hline & & & $* * 0.5606$ & 6 & $* * 0.5874$ & 3 & \\
\hline \multirow{3}{*}{$\begin{array}{l}\text { Social } \\
\text { Orientation }\end{array}$} & $* * 0.5414$ & 7 & $* * 0.4557$ & 4 & $* * 0.6105$ & 1 & \multirow{3}{*}{0.60} \\
\hline & $* * 0.4478$ & 8 & $* * 0.5622$ & 5 & $* * 0.4903$ & 2 & \\
\hline & $* * 0.4798$ & 9 & $* * 0.4458$ & 6 & $* * 0.3403$ & 3 & \\
\hline \multirow{3}{*}{$\begin{array}{l}\text { Affecting } \\
\text { Orientation }\end{array}$} & $* * 0.7037$ & 7 & $* * 0.4536$ & 4 & $* * 0.5880$ & 1 & \multirow{3}{*}{0.66} \\
\hline & & & $* * 0.4929$ & 5 & $* * 0.5567$ & 2 & \\
\hline & w.5631 & 8 & $* * 0.6110$ & 6 & $* * 0.3598$ & 3 & \\
\hline \multirow{3}{*}{$\begin{array}{l}\text { Mechanical } \\
\text { Orientation }\end{array}$} & $* * 0.7053$ & 7 & $* * 0.6893$ & 4 & $* * 0.7558$ & 1 & \multirow{3}{*}{0.85} \\
\hline & & & $* * 0.7229$ & 5 & $* * 0.7035$ & 2 & \\
\hline & *a. 7054 & 8 & $* * 0.5852$ & 6 & $* * 0.7579$ & 3 & \\
\hline \multirow{3}{*}{$\begin{array}{l}\text { Traditional } \\
\text { Orientation }\end{array}$} & $* * 0.7698$ & 7 & $* * 0.7247$ & 4 & $* * 0.3120$ & 1 & \multirow{3}{*}{0.83} \\
\hline & $* * 07200$ & & $* * 0.7651$ & 5 & $* * 0.7133$ & 2 & \\
\hline & 0.1299 & 8 & $* * 0.6167$ & 6 & $* * 0.7535$ & 3 & \\
\hline \multirow{4}{*}{$\begin{array}{l}\text { Electronic } \\
\text { Orientation }\end{array}$} & $* * 0.4276$ & 9 & $* * 0.6758$ & 5 & $* * 0.5733$ & 1 & \multirow{4}{*}{0.81} \\
\hline & & & $* * 0.6299$ & 6 & $* * 0.6663$ & 2 & \\
\hline & $* * 0.5143$ & 10 & $* * 0.5652$ & 7 & $* * 0.6664$ & 3 & \\
\hline & & & $* * 0.6499$ & 8 & $* * 0.6462$ & 4 & \\
\hline
\end{tabular}

Significant at the 0.01 level

Table 2 shows that all correlation coefficients comparing the professional orientation scale and the total degree of the dimension are statistically significant and that, consecutively, the results of internal consistency demonstrate a correlation among items. Furthermore, all items are used in measuring every aspect of professional orientation, thus substantiating the validity of the scale. As evidenced in Table 2, the validity of the measured coefficients ranges between 0.60 and 0.85 , which suggests high validity and moderate stability of the coefficients.

\section{Professional Awareness Measure}

This measure was designed by the researcher and consisted of (41) items within the following dimensions:

1. Independence in making a career decision - the individual's ability to make an independent career decision. The dimension consisted of eight items.

2. Professional information availability - the individual's ability to locate information about the job in which he or she is interested. The dimension consisted of eight items.

3. Reconciling professional and personal requirements - the individual's ability to reconcile his or her characteristics and potentialities and the requirements of the job he or she desires to pursue. The dimension consisted of nine items.

4. Interest in professional decision-making - the interests of the individual and his or her endeavors to choose a career. The dimension consisted of nine items.

5. Confirmation in making a career decision - the extent of the individual's confidence in achieving professional success in his or her chosen field. The dimension consisted of seven items. 
The respondents answered the items using a five-response Likert scale (it always applies to me, it often applies to me, it sometimes applies to me, it rarely applies to me, it does not apply to me). In designing the scale items, 17 positive and 24 negative items were included. The reliability and validity of the scale are confirmed using the following the procedures.

\section{Reliability And Validity Of The Professional Awareness Scale}

The reliability and validity of the professional awareness scale were measured using a sample of 139 female students from the community college. The validity of the scale was measured for internal consistency based on the correlation coefficient of each item, the total degree of each dimension and the total degree of the scale. The correlation coefficient between the total degree of each dimension, and the total degree of the scale was also assessed and the reliability of the scale was measured using Cronbach's alpha. Table 3 presents the reliability and validity of the professional awareness measure.

Table 3: Reliability And Validity Of Professional Awareness Measure

\begin{tabular}{|c|c|c|c|c|c|}
\hline Dimension & $\mathbf{n}$ & $\begin{array}{c}\text { Dimension } \\
\text { Correlation } \\
\text { Coefficient } \\
\end{array}$ & $\begin{array}{c}\text { Measure Total } \\
\text { Degree Correlation } \\
\text { Coefficient }\end{array}$ & $\begin{array}{c}\text { Dimension Correlation } \\
\text { Coefficient With Measure } \\
\text { Of Total Degree }\end{array}$ & $\begin{array}{c}\text { Cronbach's Alpha } \\
\text { Reliability } \\
\text { Coefficient } \\
\end{array}$ \\
\hline \multirow{8}{*}{$\begin{array}{l}\text { Independence in making } \\
\text { a professional decision }\end{array}$} & 1 & $* * 0.4361$ & $* * 0.2874$ & \multirow{8}{*}{$* * 0.7005$} & \multirow{8}{*}{0.31} \\
\hline & 6 & $* * 0.3733$ & $* * 0.3485$ & & \\
\hline & 11 & $* * 0.4619$ & $* * 0.2813$ & & \\
\hline & 16 & $* * 0.2793$ & $0.0220-$ & & \\
\hline & 21 & $* * 0.5260$ & $* * 0.5657$ & & \\
\hline & 26 & $* 0.2102$ & 0.0629 & & \\
\hline & 31 & $* * 0.4578$ & $* * 0.4675$ & & \\
\hline & 36 & $* * 0.4709$ & $* * 0.3502$ & & \\
\hline \multirow{8}{*}{$\begin{array}{l}\text { Professional information } \\
\text { availability }\end{array}$} & 2 & $* * 0.3220$ & $* * 0.3072$ & \multirow{8}{*}{$* * 0.6557$} & \multirow{8}{*}{0.62} \\
\hline & 7 & $* * 0.4566$ & $* * 0.4782$ & & \\
\hline & 12 & $* * 0.5409$ & $* * 0.3354$ & & \\
\hline & 17 & $* * 0.6288$ & $* * 0.3620$ & & \\
\hline & 22 & $* * 0.4902$ & 0.1028 & & \\
\hline & 27 & $* * 0.5081$ & $* * 0.2413$ & & \\
\hline & 32 & $* * 0.4983$ & $* * 0.3030$ & & \\
\hline & 37 & $* * 0.2374$ & $* * 0.2863$ & & \\
\hline \multirow{9}{*}{$\begin{array}{l}\text { Reconciliation between } \\
\text { personal and } \\
\text { professional } \\
\text { requirements }\end{array}$} & 3 & $* * 0.4705$ & $* * 0.3286$ & \multirow{9}{*}{$* * 0.7200$} & \multirow{9}{*}{0.62} \\
\hline & 8 & $* * 0.4700$ & $* * 0.3998$ & & \\
\hline & 13 & 0.1261 & 0.0814 & & \\
\hline & 18 & $* * 0.5161$ & $* * 0.3368$ & & \\
\hline & 23 & $* * 0.3260$ & 0.0193- & & \\
\hline & 28 & $* * 0.6263$ & $* * 0.3789$ & & \\
\hline & 33 & $* * 0.5376$ & $* * 0.4200$ & & \\
\hline & 38 & $* * 0.5362$ & $* * 0.5166$ & & \\
\hline & 40 & $* * 0.5437$ & $* * 0.5311$ & & \\
\hline \multirow{9}{*}{$\begin{array}{l}\text { Interest in making a } \\
\text { professional decision }\end{array}$} & 4 & $* * 0.4797$ & $* * 0.4521$ & \multirow{9}{*}{$* * 0.7628$} & \multirow{9}{*}{0.22} \\
\hline & 9 & $* * 0.4869$ & $* * 0.3652$ & & \\
\hline & 14 & $* 0.2051$ & 0.0785 & & \\
\hline & 19 & $* * 0.3601$ & $* * 0.4003$ & & \\
\hline & 24 & $* * 0.4218$ & $* * 0.3513$ & & \\
\hline & 29 & $* * 0.2382$ & 0.1006 & & \\
\hline & 34 & $* * 0.2742$ & $* * 0.2447$ & & \\
\hline & 39 & $* * 0.3039$ & 0.0757 & & \\
\hline & 41 & $* * 0.3206$ & $* * 0.3107$ & & \\
\hline \multirow{7}{*}{$\begin{array}{l}\text { Confirmation of making } \\
\text { a professional decision }\end{array}$} & 5 & $* * 0.4128$ & $* * 0.3597$ & \multirow{7}{*}{$* * 0.7961$} & \multirow{7}{*}{0.52} \\
\hline & 10 & $* * 0.4934$ & $* * 0.3487$ & & \\
\hline & 15 & $* * 0.4910$ & $* * 0.3648$ & & \\
\hline & 20 & $* * 0.5336$ & $* * 0.3945$ & & \\
\hline & 25 & $* * 0.5826$ & $* * 0.5089$ & & \\
\hline & 30 & $* * 0.5910$ & $* * 0.4770$ & & \\
\hline & 35 & $* * 0.4665$ & $* * 0.3904$ & & \\
\hline
\end{tabular}


Table 3 presents the following:

1. The correlation coefficients for each item and the total degree of its dimension are statistically significant, except for item (13) - reconciliation between personal and professional qualifications - which did not reach a level of statistical significance.

2. The correlation coefficients for each item and the total degree of the measure are statistically significant, except for items 13,14,16,22, 23, 26, 29, and 39 insofar as they did not reach a level of statistical significance. Therefore, these items have been removed.

3. The correlation coefficients for each dimension and the total degree of the measure are statistically significant. Accordingly, the results of the internal consistency calculations reflect item coherence for measuring professional awareness. Thus, the measure is deemed valid.

4. The reliability coefficients for the sub-dimensions of professional awareness range between $(0.22)$ and $(0.62)$ and the total reliability coefficient of the measure is high at 0.81 .

\section{Rotter's Locus Of Control Measure}

Julian Rotter developed the locus of control measure in 1966 (El-Affary, 2011) and Alaa El-Din Kfafy adapted it to the Arabian environment in 1982 (El-Affary, 2011). The measure consists of twenty-three sections, each of which contains two phrases - one represents an internal locus of control and the other represents an external locus of control. Six sections were added to the original twenty-three original sections. These six sections were not part of the final measure and were added to prevent the examinee from determining the aim of the measure and to reduce the possibility of anticipating and giving prepared responses. The examinee had to read both phrases together and then choose the one that was consistent with his or her point of view.

The responses were then scored by awarding point values for each response that indicated external/internal locus of control. The defined degree is determined by calculating the highest and the lowest quartiles of total degrees. The highest quartile represents internal locus of control and the lowest quartile represents external locus of control.

The measure's reliability was verified for the Saudi environment by reviewing the studies of Aliouby (2006) regarding teachers and those of El-Ahmady (2007) regarding preparatory and secondary female students. Both studies reached acceptable reliability coefficients and the reliabilities and stabilities of the locus of control measure were verified for the current study sample according to the following procedures.

\section{The Reliability And Stability Of The Locus Of Control Measure}

The researcher examined the reliability and stability of the locus of control measure on a sample of 139 female students from a community college. The reliability was calculated using an internal consistency process and the correlation coefficients of the locus of control items were calculated based on the total degree of the measure. The stability of the measure was calculated using Cronbach's alpha. The results for internal consistency and stability are presented in Table 4.

Table 4: Results Of Reliability And Stability Of Locus Of Control Measure

\begin{tabular}{cccccccc}
\hline $\mathbf{n}$ & $\begin{array}{c}\text { Correlation } \\
\text { Coefficient }\end{array}$ & $\mathbf{n}$ & $\begin{array}{c}\text { Correlation } \\
\text { Coefficient }\end{array}$ & $\mathbf{n}$ & $\begin{array}{c}\text { Correlation } \\
\text { Coefficient }\end{array}$ & $\begin{array}{c}\text { Correlation } \\
\text { Coefficient }\end{array}$ \\
\hline 2 & $* * 0.4283$ & 9 & $* * 0.2611$ & 16 & ${ }^{*} 0.3945$ & 23 & $* * 0.3681$ \\
\hline 3 & $* * 0.4161$ & 10 & $* * 0.2789$ & 17 & $* * 0.2931$ & 25 & $* * 0.3415$ \\
\hline 4 & $* 0.1988$ & 11 & $* * 0.4166$ & 18 & $* * 0.2853$ & 26 & $* * 0.2238$ \\
\hline 5 & $* * 0.2217$ & 12 & $* * 0.2786$ & 20 & $* * 0.2274$ & 28 & $* * 0.3160$ \\
\hline 6 & $* * 0.3407$ & 13 & $* * 0.4511$ & 21 & 0.0839 & 29 & $* * 0.2260$ \\
\hline 7 & $* * 0.2967$ & 15 & $* * 0.3520$ & 22 & $* * 0.3458$ & & \\
\hline Stability Coefficient & & & 0.56 & & & \\
\hline
\end{tabular}

$*$ is significant at the 0.05 level.

** is significant at the 0.01 level. 
Table 4 shows the correlation coefficients for the locus of control measure items. The total degree of the dimensions is statistically significant except item (21), which has been removed from the measure because it did not reach the level of statistical significance. The test for internal consistency indicates coherence of items that measure locus of control, thus reflecting the reliability of the measure. Table 4 shows that the measure's stability coefficient is $\operatorname{good}(0.56)$.

\section{Statistical Methods} - ANOVA (P).

(t) tests were administered to determine the significance of the differences between two independent groups

\section{RESULTS}

Hypothesis One: For the study sample, there are no statistically significant differences between the medians with respect to professional orientations according to the differences in locus of control (internal - external).

To confirm the validity of this hypothesis, a ( $t$ ) test was conducted to determine the significance of differences between two independent groups regarding the medians of the professional orientation measures within the study sample according to the differences in locus of control (internal-external). The results are presented in Table 5 .

Table 5: Significance Of Differences (T) Test - Differences In The Medians Of The Study Sample With Respect To Professional Orientations According To The Differences In Locus Of Control (Internal Or External)

\begin{tabular}{|c|c|c|c|c|c|c|c|}
\hline Dimension & $\begin{array}{c}\text { Sample Type (Locus } \\
\text { Of Control) }\end{array}$ & No. & $\begin{array}{c}\text { Arithmetic } \\
\text { Median }\end{array}$ & $\begin{array}{l}\text { Standard } \\
\text { Deviation } \\
\end{array}$ & (P) Value & $\begin{array}{c}\begin{array}{c}\text { Significance } \\
\text { Level }\end{array} \\
\end{array}$ & Comment \\
\hline \multirow{2}{*}{$\begin{array}{l}\text { Scientific } \\
\text { orientation }\end{array}$} & External & 51 & 39.46 & 25.78 & \multirow{2}{*}{1.13} & \multirow{2}{*}{0.263} & \multirow{2}{*}{ Insignificant } \\
\hline & Internal & 53 & 45.05 & 24.80 & & & \\
\hline \multirow{2}{*}{$\begin{array}{l}\text { Literary } \\
\text { orientation }\end{array}$} & External & 51 & 44.54 & 28.23 & \multirow{2}{*}{0.51} & \multirow{2}{*}{0.614} & \multirow{2}{*}{ Insignificant } \\
\hline & Internal & 53 & 47.17 & 24.84 & & & \\
\hline \multirow{2}{*}{$\begin{array}{l}\text { Social } \\
\text { tendencies }\end{array}$} & External & 51 & 81.92 & 16.92 & \multirow{2}{*}{1.86} & \multirow{2}{*}{0.066} & \multirow{2}{*}{ Insignificant } \\
\hline & Internal & 53 & 74.84 & 21.59 & & & \\
\hline \multirow{2}{*}{$\begin{array}{l}\text { Effective } \\
\text { orientation }\end{array}$} & External & 51 & 56.13 & 26.03 & \multirow{2}{*}{1.08} & \multirow{2}{*}{0.282} & \multirow{2}{*}{ Insignificant } \\
\hline & Internal & 53 & 50.47 & 27.29 & & & \\
\hline \multirow{2}{*}{$\begin{array}{l}\text { Mechanical } \\
\text { orientation }\end{array}$} & External & 51 & 27.45 & 26.93 & \multirow{2}{*}{0.40} & \multirow{2}{*}{0.687} & \multirow{2}{*}{ Insignificant } \\
\hline & Internal & 53 & 25.24 & 28.85 & & & \\
\hline \multirow{2}{*}{$\begin{array}{l}\text { Traditional } \\
\text { orientation }\end{array}$} & External & 51 & 51.47 & 35.68 & \multirow{2}{*}{0.64} & \multirow{2}{*}{0.521} & \multirow{2}{*}{ Insignificant } \\
\hline & Internal & 53 & 55.66 & 30.58 & & & \\
\hline \multirow{2}{*}{$\begin{array}{l}\text { Electronic } \\
\text { orientation }\end{array}$} & External & 51 & 70.39 & 25.45 & \multirow{2}{*}{2.09} & \multirow{2}{*}{0.039} & \multirow{2}{*}{$\begin{array}{l}\text { Significant at the } \\
\text { level of } 0.05\end{array}$} \\
\hline & Internal & 53 & 59.81 & 26.13 & & & \\
\hline
\end{tabular}

Table 5 indicates that the $(\mathrm{t})$ values are not significant for scientific orientation, literary orientation, social orientation, effective orientation, mechanical orientation, and traditional orientation. This finding indicates that there are no statistically significant differences between the medians of the professional orientations of the study sample for these types of professions and the differences in their locus of control (internal or external).

Table 5 further shows that the $(\mathrm{t})$ value is significant at the 0.05 level for electronic orientations, thus indicating that there are statistically significant differences between the medians of professional orientations for this type of profession and the differences in their locus of control (internal or external). Furthermore, these differences were in favor of students with an external locus of control.

This result can be explained by the fact that there are other factors that affect the choice of professional orientations, with the exception of electronic orientation, in addition to the locus of control factor. These additional factors include motivation level; that is, abilities and capabilities in a certain field, as well as social and cultural factors and previous expertise. 
The results further show that electronic orientations were affected by an external loci of control, which means that there was an external factor that affected students' decisions to pursue these orientations. The most outstanding of these external loci is the technological revolution that has made technology part of our daily lives. As a result, many highly efficient smart devices - phones, iPads and laptops, as well as the implementation of electronic programs that are not part of a traditional program, although though they include social and professional communication programs - have become extremely popular across different age groups. This is especially true for the youth from which the study sample was selected. The role of gender in the appearance of external locus of control cannot be ignored either, as some studies have found that females have a greater external locus of control than males.

This result is consistent with that of Nagy (2008) who confirmed the factors that contribute to the formation of professional orientations. These factors are represented in the personal beliefs and thoughts of the individuals with respect to the social aspects of the future professions, the nature of personal characteristics, abilities, and skills that the individual possesses, the level of knowledge and professional awareness acquired from university education, and the future expectations of the profession.

The result is also consistent with that of Karpenko (2013) who found that the social aspect of the profession in society is considered one of the greatest factors affecting the professional orientations of medical students.

Moreover, this result is consistent with that of Kara (2013) who indicated that the mastery of certain professional skills and the interest of students toward specific professional activities are two important factors that affect the professional orientations and the attitudes of the students.

With respect to gender, the results of this study are consistent with those of some studies that have indicated that some male students have high levels of internal locus of control, whereas female students display high levels of external locus of control (Aliouby, 2006; Badr, 2006; El-Ahmady, 2007; Ibrahim, 2005; Serin et al., 2010; Zaidi \& Mohsin, 2011). However, the results are inconsistent with those studies that have found that male students tend to seek help from sources of external locus of control, whereas female students tend to turn to sources of internal locus of control for assistance (Cetinkalp, 2010; Sarıçam et al., 2012).

Hypothesis Two: Are there statistically significant differences between the mean scores of female community college students with respect to professional awareness based on differences in professional orientation?

To confirm the validity of this hypothesis, a ( $\mathrm{t}$ ) test was conducted to determine the significance of differences between the two independent groups with respect to the medians of professional awareness measures for the study sample according to the differences in locus of control (internal of external). The results are presented in Table 6.

Table 6: Significance Of Differences (T) Test -

Differences In Professional Awareness According To Differences In The Locus Of Control

\begin{tabular}{|c|c|c|c|c|c|c|c|}
\hline Dimension & $\begin{array}{c}\text { Sample Type } \\
\text { (Locus Of Control) }\end{array}$ & No. & $\begin{array}{c}\text { Arithmetic } \\
\text { Median }\end{array}$ & $\begin{array}{l}\text { Standard } \\
\text { Deviation }\end{array}$ & $\begin{array}{c}(\mathbf{P}) \\
\text { Value }\end{array}$ & $\begin{array}{c}\text { Significance } \\
\text { Level }\end{array}$ & Comment \\
\hline Independence In Making A & External & 51 & 3.18 & 0.46 & \multirow{2}{*}{1.75} & \multirow{2}{*}{0.083} & \multirow{2}{*}{ Insignificant } \\
\hline Professional Decision & Internal & 53 & 3.03 & 0.40 & & & \\
\hline Professional Information & External & 51 & 2.91 & 0.50 & \multirow{2}{*}{2.63} & \multirow{2}{*}{0.010} & \multirow{2}{*}{$\begin{array}{l}\text { Significant At The } \\
\text { Level Of } 0.01\end{array}$} \\
\hline Availability & Internal & 53 & 2.66 & 0.47 & & & \\
\hline Reconciliation Between & External & 51 & 2.59 & 0.55 & \multirow[b]{2}{*}{1.80} & \multirow[b]{2}{*}{0.074} & \multirow[b]{2}{*}{ Insignificant } \\
\hline $\begin{array}{l}\text { Personal And Professional } \\
\text { Requirements }\end{array}$ & Internal & 53 & 2.41 & 0.49 & & & \\
\hline Interest In Making A & External & 51 & 2.89 & 0.41 & \multirow{2}{*}{2.30} & \multirow{2}{*}{0.024} & \multirow{2}{*}{$\begin{array}{l}\text { Significant At The } \\
\text { Level Of } 0.05\end{array}$} \\
\hline Professional Decision & Internal & 53 & 2.70 & 0.41 & & & \\
\hline Confirmation Of Making A & External & 51 & 3.07 & 0.53 & \multirow{2}{*}{2.37} & \multirow{2}{*}{0.020} & \multirow{2}{*}{$\begin{array}{l}\text { Significant At The } \\
\text { Level Of } 0.05\end{array}$} \\
\hline Professional Decision & Internal & 53 & 2.83 & 0.51 & & & \\
\hline Total Degree Of & External & 51 & 2.91 & 0.37 & \multirow[b]{2}{*}{3.08} & \multirow[b]{2}{*}{0.003} & \multirow{2}{*}{$\begin{array}{l}\text { Significant At The } \\
\text { Level Of } 0.01\end{array}$} \\
\hline $\begin{array}{l}\text { Professional Awareness } \\
\text { Measure }\end{array}$ & Internal & 53 & 2.72 & 0.29 & & & \\
\hline
\end{tabular}


Table 6 shows $(\mathrm{t})$ values at the 0.05 level and below for the availability of professional information, interest in making a professional decision, confirmation in making a professional decision, and total degree of professional awareness measures, thus indicating that there are statistically significant differences between the medians of professional awareness for acting with respect to these fields and that the differences are due to the differences in their locus of control (internal or external). These differences favor those who have an external locus of control.

This result is explained by the fact that external standards, such as social appreciation/social view of professions, and economic standards, such as receiving money/providing for needs and thus moving towards consumption, as well as certain beliefs, such as a belief in luck and coincidence, have contributed to the development of professional awareness for sample individuals more so than have personal factors, such as the level of competence and ability and self confidence. The external factors were the motivators for the sample as they were the factors that contributed to the development of students' professional awareness. This is especially the case given the characteristics of the sample - female students from a community college - as they were transferred to this college against their will because of their low academic success. Accordingly, the fact that the sample students did not choose to attend the community college and their low academic performance are factors that raised the effect of external locus of control over professional awareness.

These results are consistent with another study (Engelbrecht, 2009) which showed that people with external loci of control exhibit low levels of predictability and consistently believe that there is an external power that will affect the results they are seeking to achieve; this belief sometimes drives them to pursue goals and objectives that can be more immediately gratified rather than to work toward long-term goals.

These results are also consistent with the results of Tella and others (Tella, Tella, \& Adeniyi, 2009, p. 170) who suggested that students with external locus of control tend not to exert considerable effort to accomplish tasks as they relate their success to luck or fate.

These results are inconsistent with the studies of Serin et al. (2010) and Tella et al. (2009) which indicate that effectiveness in achieving goals, success at the academic and personal levels, the desire to learn, the gathering of information, and a positive attitude toward academic environments are the results of internal locus of control.

Hypothesis Three: For the study sample, there are no statistically significant differences between the medians with respect to professional awareness according to the differences in professional orientations.

To confirm the validity of this hypothesis, a ( $t$ ) test was conducted to determine the significance of differences between more than two independent groups with respect to the differences in professional awareness according to the differences in professional orientations. The results are presented in Table 7.

Table 7: Significance Of Differences ANOVA (P) Test -

Differences In Professional Awareness Measures According To Differences In Professional Orientations

\begin{tabular}{|c|c|c|c|c|c|c|c|}
\hline Dimension & $\begin{array}{l}\text { Difference } \\
\text { Source }\end{array}$ & $\begin{array}{l}\text { Squares } \\
\text { Total }\end{array}$ & $\begin{array}{l}\text { Freedom } \\
\text { Degrees }\end{array}$ & $\begin{array}{l}\text { Squares } \\
\text { Median }\end{array}$ & $\begin{array}{c}(\mathbf{P}) \\
\text { Value }\end{array}$ & $\begin{array}{c}\text { Significance } \\
\text { Level }\end{array}$ & Comment \\
\hline $\begin{array}{l}\text { Independence in making a } \\
\text { professional decision }\end{array}$ & $\begin{array}{l}\text { Between groups } \\
\text { Within groups }\end{array}$ & $\begin{array}{c}0.66 \\
28.41\end{array}$ & $\begin{array}{c}6 \\
159\end{array}$ & $\begin{array}{l}0.11 \\
0.18\end{array}$ & 0.62 & 0.716 & Insignificant \\
\hline $\begin{array}{l}\text { Professional information } \\
\text { availability }\end{array}$ & $\begin{array}{l}\text { Between groups } \\
\text { Within groups }\end{array}$ & $\begin{array}{c}0.63 \\
40.73\end{array}$ & $\begin{array}{c}6 \\
159\end{array}$ & $\begin{array}{l}0.11 \\
0.26\end{array}$ & 0.41 & 0.871 & Insignificant \\
\hline $\begin{array}{l}\text { Reconciliation between } \\
\text { personal and professional } \\
\text { requirements }\end{array}$ & $\begin{array}{l}\text { Between groups } \\
\text { Within groups }\end{array}$ & $\begin{array}{c}1.97 \\
40.97\end{array}$ & 159 & $\begin{array}{l}0.33 \\
0.26\end{array}$ & 1.27 & 0.272 & Insignificant \\
\hline $\begin{array}{l}\text { Interest in making a } \\
\text { professional decision }\end{array}$ & $\begin{array}{l}\text { Between groups } \\
\text { Within groups }\end{array}$ & $\begin{array}{c}0.54 \\
25.62\end{array}$ & $\begin{array}{c}6 \\
159\end{array}$ & $\begin{array}{l}0.09 \\
0.16\end{array}$ & 0.56 & 0.765 & Insignificant \\
\hline $\begin{array}{l}\text { Confirmation of making a } \\
\text { professional decision }\end{array}$ & $\begin{array}{l}\text { Between groups } \\
\text { Within groups }\end{array}$ & $\begin{array}{l}1.13 \\
0.66\end{array}$ & $\begin{array}{l}6 \\
6\end{array}$ & $\begin{array}{l}0.19 \\
0.11\end{array}$ & 0.69 & 0.655 & Insignificant \\
\hline $\begin{array}{l}\text { Total degree of professional } \\
\text { awareness measure }\end{array}$ & $\begin{array}{l}\text { Between groups } \\
\text { Within groups }\end{array}$ & $\begin{array}{c}0.19 \\
17.99\end{array}$ & $\begin{array}{c}6 \\
159 \\
\end{array}$ & $\begin{array}{l}0.03 \\
0.11\end{array}$ & 0.28 & 0.945 & Insignificant \\
\hline
\end{tabular}


Table 7 shows that $(\mathrm{p})$ values are insignificant with respect to independence in making a professional decision, professional information availability, reconciliation between personal and professional requirements, interest in making a professional decision, confirmation of making a professional decision, and total degree of professional awareness, thus indicating that there are no statistically significant differences between the medians of professional awareness for the study sample in these fields due to their professional orientations.

These results are likely because, even though the students have different professional orientations, they have not contributed to developing their professional awareness, which may be due to the weak professional preparation students receive during the early academic stages. The lack of interest in developing professional orientations in the early academic years, accordingly, resulted in students' low levels of professional awareness.

This result is consistent with the finding of McKnight (2009) which indicates that the lack of interest in developing students' professional orientations within the academic environment during the early stages has led to students failing to plan for their professional careers until the final year of their secondary education. This late planning process means students are unable to make effective decisions regarding their future professions. Further contributing to this situation is the failure to allocate sufficient levels of financial resources to training activities and programs aimed to improve professional orientation awareness among students.

Hypothesis Four: For the study sample, there are no statistically significant differences between the medians with respect to professional orientations according to the differences in academic specialization.

To confirm the validity of this hypothesis, an ANOVA test (p) was conducted to determine the significance of the differences between more than two independent groups and to determine if the differences with respect to professional awareness were due to specialization. The results are presented in Table 8.

Table 8: Significance Of Differences ANOVA (P) Test -

Differences In Professional Awareness Measures According To Differences In Specialization

\begin{tabular}{|c|c|c|c|c|c|c|c|}
\hline Dimension & Difference Source & $\begin{array}{c}\text { Squares } \\
\text { Total }\end{array}$ & $\begin{array}{c}\text { Freedom } \\
\text { Degrees }\end{array}$ & $\begin{array}{l}\text { Squares } \\
\text { Median }\end{array}$ & (P) Value & $\begin{array}{c}\begin{array}{c}\text { Significance } \\
\text { Level }\end{array} \\
\end{array}$ & Comment \\
\hline $\begin{array}{l}\text { Scientific } \\
\text { orientation }\end{array}$ & $\begin{array}{l}\text { Between groups } \\
\text { Within groups }\end{array}$ & $\begin{array}{c}5283.81 \\
109265.33\end{array}$ & $\begin{array}{c}3 \\
162 \\
\end{array}$ & $\begin{array}{c}1761.27 \\
674.48 \\
\end{array}$ & 2.61 & 0.053 & Significant at 0.05 \\
\hline $\begin{array}{l}\begin{array}{l}\text { Literary } \\
\text { orientation }\end{array} \\
\end{array}$ & $\begin{array}{l}\text { Between groups } \\
\text { Within groups }\end{array}$ & $\begin{array}{c}2189.98 \\
113389.07 \\
\end{array}$ & $\begin{array}{c}3 \\
162 \\
\end{array}$ & $\begin{array}{l}729.99 \\
699.93 \\
\end{array}$ & 1.04 & 0.375 & Insignificant \\
\hline $\begin{array}{l}\begin{array}{l}\text { Social } \\
\text { orientation }\end{array} \\
\end{array}$ & $\begin{array}{c}\text { Between groups } \\
\text { Within groups }\end{array}$ & $\begin{array}{c}2359.52 \\
66774.05 \\
\end{array}$ & $\begin{array}{c}3 \\
162 \\
\end{array}$ & $\begin{array}{l}786.51 \\
412.19 \\
\end{array}$ & 1.91 & 0.130 & Insignificant \\
\hline $\begin{array}{l}\begin{array}{l}\text { Effective } \\
\text { orientation }\end{array} \\
\end{array}$ & $\begin{array}{l}\text { Between groups } \\
\text { Within groups }\end{array}$ & $\begin{array}{c}2679.98 \\
104794.60 \\
\end{array}$ & $\begin{array}{c}3 \\
162 \\
\end{array}$ & $\begin{array}{l}893.33 \\
646.88 \\
\end{array}$ & 1.38 & 0.251 & Insignificant \\
\hline $\begin{array}{l}\text { Mechanical } \\
\text { orientation }\end{array}$ & $\begin{array}{l}\text { Between groups } \\
\text { Within groups }\end{array}$ & $\begin{array}{c}3418.05 \\
148027.73\end{array}$ & $\begin{array}{c}3 \\
162\end{array}$ & $\begin{array}{c}1139.35 \\
913.75\end{array}$ & 1.25 & 0.295 & Insignificant \\
\hline $\begin{array}{l}\text { Traditional } \\
\text { orientation }\end{array}$ & $\begin{array}{l}\text { Between groups } \\
\text { Within groups }\end{array}$ & $\begin{array}{c}8124.18 \\
180332.14 \\
\end{array}$ & $\begin{array}{c}3 \\
162 \\
\end{array}$ & $\begin{array}{l}2708.06 \\
1113.16 \\
\end{array}$ & 2.43 & 0.067 & Insignificant \\
\hline $\begin{array}{l}\text { Electronic } \\
\text { orientation }\end{array}$ & $\begin{array}{l}\text { Between groups } \\
\text { Within groups }\end{array}$ & $\begin{array}{c}13430.49 \\
112632.77 \\
\end{array}$ & $\begin{array}{c}3 \\
162 \\
\end{array}$ & $\begin{array}{c}4476.83 \\
695.26 \\
\end{array}$ & 6.44 & 0.000 & Significant at 0.01 \\
\hline
\end{tabular}

Table 8 suggests that the (p) values are not significant with respect to literary orientation, social orientation, effective orientation, mechanical orientation, or traditional orientation, thus indicating that there are no statistically significant differences between the medians of professional orientations for these types of professions related to their specialization.

Table 8 also shows that (p) values are significant at the 0.01 level for scientific orientation and electronic orientation, which indicates that there are statistically significant differences between the medians of professional orientations for these types of professions in relation to the their specialization. The Scheffe test was used to discover the source of these differences and the results are presented in Table 9. 
Table 9: Scheffe Test - Differences In Professional Orientations According To Differences In Specialization

\begin{tabular}{|c|c|c|c|c|c|c|c|}
\hline Dimension & Specialty & $\begin{array}{c}\text { Arithmetic } \\
\text { Median }\end{array}$ & $\begin{array}{c}\text { Business } \\
\text { Administration }\end{array}$ & $\begin{array}{c}\text { Office } \\
\text { Administration }\end{array}$ & $\begin{array}{c}\text { Sales \& } \\
\text { Marketing }\end{array}$ & Computer & $\begin{array}{c}\text { Difference In } \\
\text { Favor Of }\end{array}$ \\
\hline \multirow{4}{*}{$\begin{array}{l}\text { First } \\
\text { group** }\end{array}$} & $\begin{array}{l}\text { Business } \\
\text { administration }\end{array}$ & 45.75 & & & & & \\
\hline & $\begin{array}{l}\text { Office } \\
\text { administration }\end{array}$ & 38.52 & & & & & \\
\hline & Sales \& marketing & 38.44 & & & & & \\
\hline & computer & 53.70 & & $*$ & $*$ & & Computer \\
\hline \multirow{4}{*}{$\begin{array}{l}\text { Seventh } \\
\text { group }\end{array}$} & $\begin{array}{l}\text { Business } \\
\text { administration }\end{array}$ & 64.40 & & & & & \\
\hline & $\begin{array}{l}\text { Office } \\
\text { management }\end{array}$ & 56.12 & & & & & \\
\hline & Sales \& marketing & 61.25 & & & & & \\
\hline & Computer & 83.33 & $*$ & $*$ & $*$ & & Computer \\
\hline
\end{tabular}

Table 9 indicates that there are significant differences at the 0.05 level.

1. There are significant differences in scientific orientation between students specializing in office administration and sales and marketing and students specializing in computer technology. The difference is in favor of students specializing in computer technology.

2. There are significant differences between students specializing in business administration, office administration, and sales and marketing and students specializing in computer technology. The difference is in favor of students specializing in computer technology.

The researcher explains these results in light of the existence of differences in scientific and electronic orientations among specializations and notes that these differences favor (computer) specialization. This is likely because the department of computer and information technologies only accepts students who have graduated from the science division of their secondary schools. With respect to electronic orientations, it is normal that students who study in the computer department would exhibit greater electronic orientation than students who study in other specializations.

These findings are consistent with a number of studies, such as that of El-Khatieb (2005), which showed differences in professional environments related to different academic specializations - scientific, literary, industrial, commercial, and agricultural - for secondary school students and that of Mahmud (1999) which showed that students in the scientific domain tend more than students in the literary division toward special professional groups.

These results are partly consistent with the El-Refoa (1995) study which showed no statistically significant differences between scientific and literary domains in the real environment. It also showed, however, that there are differences with respect to the rest of the professional environments for secondary school students, both males and females. The results are also consistent with the study by Elias (1993) which showed the superiority of students in the science domain over those in the literary division with respect to scientific and mechanical orientations as well as in tendencies toward literature, music, and social services.

Hypothesis Five: For the study sample, there are no statistically significant differences between the medians with respect to professional awareness according to the differences in academic specialization.

To confirm the validity of this hypothesis, an ANOVA test (p) was conducted to determine the significance of differences between more than two independent groups and the study sample with respect to professional awareness according to the differences in specialization. The results are presented in Table 10. 
Table 10: Significance Of Differences ANOVA (P) Test -

Differences In Professional Awareness Measures According To Differences In Specialization

\begin{tabular}{|c|c|c|c|c|c|c|c|}
\hline Dimension & $\begin{array}{l}\text { Difference } \\
\text { Source }\end{array}$ & $\begin{array}{c}\text { Squares } \\
\text { Total }\end{array}$ & $\begin{array}{c}\text { Freedom } \\
\text { Degrees }\end{array}$ & $\begin{array}{l}\text { Squares } \\
\text { Median }\end{array}$ & $\begin{array}{c}(\mathbf{P}) \\
\text { Value }\end{array}$ & $\begin{array}{c}\begin{array}{c}\text { Significance } \\
\text { Level }\end{array} \\
\end{array}$ & Comment \\
\hline $\begin{array}{l}\text { Independence in making } \\
\text { a professional decision }\end{array}$ & $\begin{array}{l}\text { Between groups } \\
\text { Within groups }\end{array}$ & $\begin{array}{c}0.08 \\
28.99\end{array}$ & $\begin{array}{c}3 \\
162\end{array}$ & $\begin{array}{l}0.03 \\
0.18\end{array}$ & 0.15 & 0.932 & Insignificant \\
\hline $\begin{array}{l}\text { Professional information } \\
\text { availability }\end{array}$ & $\begin{array}{l}\text { Between groups } \\
\text { Within groups }\end{array}$ & $\begin{array}{c}0.86 \\
40.51\end{array}$ & $\begin{array}{c}3 \\
162\end{array}$ & $\begin{array}{l}0.29 \\
0.25\end{array}$ & 1.14 & 0.334 & Insignificant \\
\hline $\begin{array}{l}\text { Reconciliation between } \\
\text { personal \& professional } \\
\text { requirements }\end{array}$ & $\begin{array}{l}\text { Between groups } \\
\text { Within groups }\end{array}$ & 42.40 & 162 & 0.18 & 0.68 & 0.565 & Insignificant \\
\hline $\begin{array}{l}\text { Interest in making a } \\
\text { professional decision }\end{array}$ & $\begin{array}{l}\text { Between groups } \\
\text { Within groups }\end{array}$ & $\begin{array}{c}0.30 \\
25.86\end{array}$ & $\begin{array}{c}3 \\
162\end{array}$ & $\begin{array}{l}0.10 \\
0.16\end{array}$ & 0.63 & 0.596 & Insignificant \\
\hline $\begin{array}{l}\text { Confirmation of making } \\
\text { a professional decision }\end{array}$ & $\begin{array}{l}\text { Between groups } \\
\text { Within groups }\end{array}$ & $\begin{array}{c}0.88 \\
43.53 \\
\end{array}$ & $\begin{array}{c}3 \\
162 \\
\end{array}$ & $\begin{array}{l}0.30 \\
0.27 \\
\end{array}$ & 1.10 & 0.352 & Insignificant \\
\hline $\begin{array}{l}\text { Total degree of } \\
\text { professional awareness } \\
\text { measure }\end{array}$ & $\begin{array}{l}\text { Between groups } \\
\text { Within groups }\end{array}$ & $\begin{array}{c}0.01 \\
18.18\end{array}$ & $\begin{array}{c}3 \\
162\end{array}$ & $\begin{array}{l}0.00 \\
0.11\end{array}$ & 0.02 & 0.996 & Insignificant \\
\hline
\end{tabular}

Table 10 shows that $(\mathrm{p})$ values are insignificant with respect to independence in making a professional decision, professional information availability, reconciliation between personal and professional requirements, interest in making professional decisions, confirmation in making a professional decision, and total degree of professional awareness, thus indicating that there are no statistically significant differences between the medians of professional awareness for the study sample in these fields due to their specializations.

The above results can be explained in light of the convergence of specializations because all students in the study are from either administrative specializations, such as business administration, office management, sales and marketing, etc., or are enrolled in the computer technology department. It could also be due to the characteristics of the sample, as most of the sampled students were transferred to the community college against their will because of low academic achievement or because of having stumbled in their preparatory year.

Hypothesis Six: For the study sample, there are no statistically significant differences between the medians with respect to professional tendencies according to the differences in stumbling academically (not at risk - at risk).

To confirm the validity of this hypothesis, a ( $t$ ) test was conducted to determine the significance of differences between two independent groups. The significance of differences between the medians of the study sample with respect to professional orientations according to sample type (not at risk - at risk) was determined. The results are presented in Table 11.

Table 11: Significance Of Differences (T) Test - Differences In Professional Tendencies Measure According Academic Stumbles

\begin{tabular}{|c|c|c|c|c|c|c|c|}
\hline Dimension & $\begin{array}{c}\text { Sample's Type } \\
\text { (Academic Stumble) }\end{array}$ & No. & $\begin{array}{l}\text { Arithmetic } \\
\text { Median }\end{array}$ & $\begin{array}{l}\text { Standard } \\
\text { Deviation }\end{array}$ & (T) Value & $\begin{array}{c}\begin{array}{c}\text { Significance } \\
\text { Level }\end{array} \\
\end{array}$ & Comment \\
\hline \multirow{2}{*}{$\begin{array}{l}\text { Scientific } \\
\text { orientation }\end{array}$} & Not at risk & 108 & 44.33 & 25.94 & \multirow{2}{*}{0.62} & \multirow{2}{*}{0.537} & \multirow{2}{*}{ Insignificant } \\
\hline & At risk & 57 & 41.67 & 26.86 & & & \\
\hline \multirow{2}{*}{$\begin{array}{l}\begin{array}{l}\text { Literary } \\
\text { orientation }\end{array} \\
\end{array}$} & Not at risk & 108 & 47.22 & 27.17 & \multirow{2}{*}{0.20} & \multirow{2}{*}{0.843} & \multirow{2}{*}{ Insignificant } \\
\hline & At risk & 57 & 46.37 & 24.78 & & & \\
\hline \multirow{2}{*}{$\begin{array}{l}\text { Social } \\
\text { orientation }\end{array}$} & Not at risk & 108 & 80.35 & 19.78 & \multirow{2}{*}{1.11} & \multirow{2}{*}{0.270} & \multirow{2}{*}{ Insignificant } \\
\hline & At risk & 57 & 76.80 & 19.16 & & & \\
\hline \multirow{2}{*}{$\begin{array}{l}\text { Effective } \\
\text { orientation }\end{array}$} & Not at risk & 108 & 52.20 & 23.23 & \multirow{2}{*}{0.48} & \multirow{2}{*}{0.630} & \multirow{2}{*}{ Insignificant } \\
\hline & At risk & 57 & 54.39 & 29.74 & & & \\
\hline \multirow{2}{*}{$\begin{array}{l}\text { Mechanical } \\
\text { orientation }\end{array}$} & Not at risk & 108 & 26.04 & 29.41 & \multirow{2}{*}{1.52} & \multirow{2}{*}{0.130} & \multirow{2}{*}{ Insignificant } \\
\hline & At risk & 57 & 33.55 & 31.62 & & & \\
\hline \multirow{2}{*}{$\begin{array}{l}\text { Traditional } \\
\text { orientation }\end{array}$} & Not at risk & 108 & 53.82 & 33.55 & \multirow{2}{*}{0.25} & \multirow{2}{*}{0.800} & \multirow{2}{*}{ Insignificant } \\
\hline & At risk & 57 & 52.41 & 34.27 & & & \\
\hline \multirow{2}{*}{$\begin{array}{l}\text { Electronic } \\
\text { orientation }\end{array}$} & Not at risk & 108 & 65.19 & 27.50 & \multirow{2}{*}{0.34} & \multirow{2}{*}{0.738} & \multirow{2}{*}{ Insignificant } \\
\hline & At risk & 57 & 63.68 & 27.03 & & & \\
\hline
\end{tabular}


Table 11 shows that (p) values are not significant with respect to scientific orientation, literary orientation, social orientation, effective orientation, mechanical orientation, traditional orientation, and electronic orientation, thus indicating that there are no statistically significant differences among the medians of professional orientations of the study sample individuals for these types of professions compared to the differences in the sample type in terms of the degree of stumbling academically (not at risk - at risk).

These results emerged because no differences were found in professional orientations with respect to stumbling academically due to the convergence of the individuals in academic achievement; that is, $87.8 \%$ of the achievement levels range between 2 and 3.99. Furthermore, the sample of students were subjected to the same conditions of enrollment (community college), which means they either had a prior achievement rate of 2.75 or less or they stumbled in their preparatory year.

These results are consistent with the findings of Luzz (1993, as cited in El-Khatieb, 2005), who determined that there was no relations between professional orientations and academic success of university students.

Furthermore, the results are partly consistent with those of El-Khatieb (2005), which showed that there was no relation among academic achievement and real and social professional environments but that there was a relationship among exploratory, literary, adventurous and traditional professional environments and academic achievement.

Moreover, the results are partly consistent with El-Shenawy (1993) who indicated that there was no relation between professional orientations and academic achievement in the scientific domain and that there was a negative correlation between academic achievement and professional orientations of industrial secondary schools because it was determined that there was a relation between some professional orientations and academic achievement in certain specializations.

This result, however, is inconsistent with $\mathrm{Wu}$ and Tien (2000, as cited in El-Khatieb, 2005), who found a statistically significant relation between professional orientations and academic achievement among Chinese secondary students.

Hypothesis Seven: For the study sample, there are no statistically significant differences between the medians with respect to professional awareness according to the differences in stumbling academically (not at risk - at risk).

To confirm the validity of this hypothesis, a (t) test was conducted to determine the significance of the differences between two independent groups. The significance of differences between the medians of the study sample with respect to professional awareness according to the sample type, stumbling academically (not at risk - at risk) was determined. The results are presented in Table 12.

Table 12: Significance Of Differences ((T) Test) -

Differences In Professional Awareness Measures According To Stumbling Academically

\begin{tabular}{|c|c|c|c|c|c|c|c|}
\hline Dimension & $\begin{array}{c}\text { Sample Type } \\
\text { (Stumbling Academically) }\end{array}$ & No. & $\begin{array}{l}\text { Arithmetic } \\
\text { Median }\end{array}$ & $\begin{array}{l}\text { Standard } \\
\text { Deviation }\end{array}$ & $\begin{array}{c}(\mathbf{P}) \\
\text { Value }\end{array}$ & $\begin{array}{c}\text { Significance } \\
\text { Level }\end{array}$ & Comment \\
\hline \multirow{2}{*}{$\begin{array}{l}\text { Independence in making } \\
\text { professional choice }\end{array}$} & Not at risk & 108 & 3.09 & 0.42 & \multirow{2}{*}{1.03} & \multirow{2}{*}{0.303} & \multirow{2}{*}{ Insignificant } \\
\hline & At risk & 57 & 3.02 & 0.40 & & & \\
\hline \multirow{2}{*}{$\begin{array}{l}\text { Professional information } \\
\text { availability }\end{array}$} & Not at risk & 108 & 2.76 & 0.48 & \multirow{2}{*}{0.09} & \multirow{2}{*}{0.931} & \multirow{2}{*}{ Insignificant } \\
\hline & At risk & 57 & 2.77 & 0.55 & & & \\
\hline \multirow{2}{*}{$\begin{array}{l}\text { Reconciliation between } \\
\text { personal and professional } \\
\text { requirements }\end{array}$} & Not at risk & 108 & 2.60 & 0.45 & \multirow{2}{*}{2.52} & \multirow[b]{2}{*}{0.013} & \multirow{2}{*}{$\begin{array}{c}\text { Significant at } \\
0.01 \text { level }\end{array}$} \\
\hline & At risk & 57 & 2.39 & 0.57 & & & \\
\hline \multirow{2}{*}{$\begin{array}{l}\text { Interest in making } \\
\text { professional decision }\end{array}$} & Not at risk & 108 & 2.85 & 0.39 & \multirow{2}{*}{1.50} & \multirow{2}{*}{0.135} & \multirow{2}{*}{ Insignificant } \\
\hline & At risk & 57 & 2.75 & 0.41 & & & \\
\hline \multirow{2}{*}{$\begin{array}{l}\text { Confirmation of professional } \\
\text { decision }\end{array}$} & Not at risk & 108 & 2.98 & 0.49 & \multirow{2}{*}{1.66} & \multirow{2}{*}{0.099} & \multirow{2}{*}{ Insignificant } \\
\hline & At risk & 57 & 2.84 & 0.55 & & & \\
\hline \multirow{2}{*}{$\begin{array}{l}\text { Total degree of professional } \\
\text { awareness measure }\end{array}$} & Not at risk & 108 & 2.85 & 0.28 & \multirow{2}{*}{1.72} & \multirow{2}{*}{0.088} & \multirow{2}{*}{ Insignificant } \\
\hline & At risk & 57 & 2.75 & 0.39 & & & \\
\hline
\end{tabular}


Table 12 shows that the $(\mathrm{t})$ values are insignificant in the following dimensions: independence in making professional choice, professional information availability, interest in making a professional decision, confirmation of a professional decision, and the total degree of professional awareness. This lack of significance indicates that there are not statistically significant differences between the medians of professional awareness for the study sample in these fields compared to the differences in the sample type of stumbling academically (not at risk - at risk).

Table 12 also indicates that the (t) value is significant at the 0.01 level for the reconciliation between personal and professional requirements dimension, which suggests that there are statistically significant differences between the medians of professional awareness for the individuals in the study sample in this field compared to the differences in sample type with respect to stumbling academically (not at risk - at risk). Furthermore, these differences were in favor of those students identified as not being at risk, a result that is explained according to the result of the previous hypothesis.

\section{AUTHOR INFORMATION}

Dr. Nourah Abdulrhman Algadheeb; Assistant Professor of Psychology; Ph.D. in Psychology, Nourah Bint Abdulrahman University (2008); Head of the Department of Education and Psychology (2009-2011); Deputy Head of the Talented Students Section at the Faculty of Education (2007-2009); Member of the Saudi Society for Psychological Measurement; Member of the Saudi Educational and Psychological Association; Member of the Egyptian Association for Psychological Studies; Member of the Saudi Psychiatric Association. Email: drnorah08@gmail.com.

\section{REFERENCES}

1. Aliouby, A. (2006). Point of control and its relationship with each of rational and irrational thoughts and psychological burnout of a sample of primary stage's female teachers at Yanbu (Unpublished Master's thesis). Om ElQora University, Makkah, Kingdom of Saudi Arabia.

2. Al-Mohammdy, M. (2004). Rational and irrational thoughts and their relationship with internal and external point of control of a sample of teachers faculty's students at Jeddah (Unpublished Master's thesis). Om ElQora University, Makkah, Kingdom of Saudi Arabia.

3. Al-Murabit, I. A. (2012). A closer look at an English language curriculum of a community college in Saudi Arabia. English Language Teaching, 5(8), 226-242.

4. Ari, E., Vatansever, F., \& Uzun, A. (2009). Student professional orientation using fuzzy logic rules and quality. 6th Research/Expert Conference With International Participations “Quality 2009”, June 04 - 07, Neum, B\&H.

5. Austin, M. L. (2008). Evaluation of a criminal justice career program implemented within a community college (Unpublished doctoral dissertation). Nova Southeastern University, Fort Lauderdale, FL.

6. Ayodele, K. O. (2013). Demographics, entrepreneurial self-efficacy and locus of control as determinants of adolescents' enrepreneurial intention in Ogun State, Nigeria. European Journal of Business and Social Sciences, 1(12), 59-67.

7. Badr, F. (2006). Locus of control and self-confirmation: a comparative study between university students living in KSA and living outside if it. Journal of Arabic Studies in Psychology, 5(1), 11-43.

8. Bailey, T. R., \& Alfonso, M. (2005). Paths to persistence: an analysis of research on program effectiveness at community colleges. Community College Research Center, 6(1), 1-3 .

9. Bernardi, R. A. (2013). The relationships among locus of control, perceptions of stress, and performance. Journal of Applied Business Research, 13(4), 1-8.

10. Bradley, C. A. (2009). Career paths, barriers, and professional experiences: a comparison study of African American community college presidents and white community college presidents (Unpublished doctoral dissertation). Mississippi State University, Mississippi State, MS.

11. Carter, L. S. (2009). The philanthropic motivations of community college donors: a study of the educational foundation of a mid-sized, multi-campus community college in Virginia (Unpublished doctoral dissertation). Old Dominion University, Norfolk, VA.

12. Cetinkalp, Z. K. (2010). The relationship between academic locus of control and achievement goals among physical education teaching program students. World Applied Sciences Journal, 10(11), 1387-1391. 
13. Crawford, C., \& Jervis, A. (2011). Community college today. Contemporary Issues in Education Research, 4(8), 29-32.

14. Davis, D. R. (2009). Survey of articulation and transfer issues in Mississippi's community college art programs (Unpublished doctoral dissertation). Mississippi State University, Mississippi State, MS.

15. El-Affary, Ibtsam. (2011). The relationship between point of control and the major five factors in personality of a sample of Om ElQora university's female students at Mecca (Unpublished Master's thesis). Om ElQora University, Makkah, Kingdom of Saudi Arabia.

16. El-Ahmady, S. (2007). Feeling of psychological loneliness and its relationship with locus of control and psychological pressures for a sample of female teenagers at Mecca (Unpublished Master's thesis). Om ElQora University, Makkah, Kingdom of Saudi Arabia.

17. El-Ewies, R. (2007). The orientations and their relationship with types of personality of girls excelling in academic achievement in the twelve grade at UAE (Unpublished Master's thesis). Gulf University, Manamah. Bahrain.

18. El-Harby, H. (2006). Beliefs of public and academic efficiency and point of control and their relationship with academic achievement in the light of some demographical and academic variables for a sample of male and female students at Om El-Qora University (Unpublished Master's thesis). Om El-Qora University, Makkah, Kingdom of Saudi Arabia.

19. El-Hekmy, I. (2004). The effect of academic specialty and locus of control on personal intelligence of Om El-Qora university's students - El-Ta'ef branch. Journal of Om El-Qora University for Educational, Social, and Human Sciences, 6(1), 166-218.

20. Elias, F. (1993). Educational guidance to the types of secondary education in Sultanate of Oman from the entrance of professional tendencies (dissertation).

21. El-Khatieb, S. (2005). Professional orientations of secondary stage's students at UAE and their relationship with academic achievement and academic specialty. Journal of Universities Union in Education and Psychology, 3(1), 43-85.

22. El-Mazroa, L. (2008). Cognitive independence and its relationship with locus of control and the motive of academic achievement of sample of secondary stage's female students at Mecca: a comparative study between excelling and belated academically students. Journal of Contemporary Psychology for Human Sciences, 9, 239-294.

23. El-Refoa, A. (1995). The relationship of sensual and intuitive types of personality with professional choice for second secondary grade's students at the south region in Jordan (Unpublished Master's thesis). Mo'ta University, Mo'ta, Jordan.

24. El-Shagrawy, S. (2005). Methods of social control and their relationship with the self-concept and locus of control for basic stage's students within Jordanian schools (Unpublished doctoral dissertation). Amman Arabian University, Amman, Jordan.

25. El-Shenawy, M. (1993). Professional orientations and academic specialty of secondary and university students. Journal of Psychological Guidance, 1, 24-54.

26. Engelbrecht, C. (2009). Determining the construct validity of Udai Pareek's locus of control inventory (Unpublished Master's thesis). University of Pretoria, Hatfield, South Africa.

27. Fisher, K. (2009). Service on the community college campus: the millennial generation perspective (Unpublished doctoral dissertation). Iowa State University, Ames, IA.

28. Furchtgott-Roth, D., Jacobson, L., \& Mokher, C. (2009). Strengthening community colleges' influence on economic mobility. Washington, DC: Economic Mobility Project: An Initiative of the Pew Charitable Trusts.

29. Gascon-Brewton, J. M. (2011). Developing future Texas community college leaders (Unpublished doctoral dissertation). University of Houston, Houston, TX.

30. Gerber, M., Wittekind, A., Grote, G., \& Staffelbach, B. (2009). Exploring types of career orientation: a latent class analysis approach. Journal of Vocational Behavior, 75(3), 303-318.

31. Helmer, S. M., Krämer, A., \& Mikolajczyk, R. T. (2012). Health-related locus of control and health behaviour among university students in North Rhine Westphalia, Germany. BMC Research Notes, 5, 1-8.

32. Henderson, K. M. (2009). The effects of a cognitive information processing career intervention on the dysfunctional career thoughts, locus of control, and career decision self-efficacy of underprepared college students (Unpublished doctoral dissertation). Kansas State University, Manhattan, KS.

33. Hill, D. W. (2007). High school guidance counselors' perceptions of community colleges in a mid-Atlantic 
state (Unpublished doctoral dissertation). Morgan State University, Baltimore, MD.

34. Hull, M. S. (2004). Corporate fund-raising strategies in public community colleges (Unpublished doctoral dissertation). University of Virginia, Charlottesville, VA.

35. Ibrahim, A.-H. (2003). Professional interests: a comparative study according to the specialty and academic achievement and parents' education of a sample of Emirates university's students. Social Affairs, 79, 22-58.

36. Ibrahim, M. (2005). Locus of control and rational preference and their relationship with some demographical variables of Kuwaiti students and employee of both genders. Journal of Social Sciences, 33(2), 337-376.

37. Kalantarkousheh, S. M., Mohagheghi, H., \& Hosseini, S. M. (2013). Surveying the relationship between locus of control and academic achievement among students at Allameh Tabataba'i University. International Journal of Physical and Social Sciences, 3(12), 378-389.

38. Kara, S. I. (2013). An improvement of process of organization of pedagogical practice is priority condition of forming of professional competence of future teachers the basics of health. Medical-Biological Problems of Physical Training And Sports, 11, 28-31.

39. Karpenko, K. (2013). New reproductive technologies and politics of choice. The Third International Conference "The Future Of Education", 13-14 June, Florence, Italy.

40. Kelly, K. E., \& Kneipp, L. B. (2004). You do what you are: the relationship between the scale of creative attributes and behavior and vocational interest. Journal of International Psychology, 36(1), 79-83.

41. Klyoopi, K. (2009). Social responsibility and its relationship with point of control and self-efficacy of a sample of students within King Abdul-Aziz University at Jeddah (Unpublished doctoral dissertation). Om ElQura University, Makkah, Kingdom of Saudi Arabia.

42. Kutanis, R. Ö., Mesci, M., \& Övdür, Z. (2011). The effects of locus of control on learning performance: a case of an academic organization. Journal of Economic and Social Studies, 1(2), 113-133.

43. Lami, R., \& Mile, K. (2013). Neoliberalism effects in Albanian higher education. Journal of International Academic Research for Multidisciplinary, 11, 487-494.

44. Li, P. (2012). An investigative research on professional awareness of free normal students (Master's thesis). Retrieved from: http://www.Globethesis.Com/?T=2217330368495927.

45. Lovell, C. D. (2007). Community colleges in the West: the expansion of this critical sector of postsecondary education. Journal of Applied Research in the Community College, 15(1), 57-66.

46. Luna, B. A. (2007). Needs and changing missions: post North American Free Trade Agreement workforce development in community colleges along the Texas-Mexico border (Unpublished doctoral dissertation). Capella University (online).

47. Mahmud, M. (1999). The professional orientations and their relationship with sex, specialty, and professional maturity of second secondary grade's students (Unpublished Master's thesis). Jordanian University, Amman, Jordan.

48. Manias, N. (2007). The baccalaureate community colleges in Florida: a policy evaluation (Unpublished doctoral dissertation). University of South Florida, Tampa, FL.

49. McKnight, M. A. (2009). Career orientation decisions of rural high school students: a case study. Journal of Human Resource and Adult Learning, 5(2), 1-11.

50. Mekdad, M., \& Hussein, K. (2011). Professional orientations and multiple intelligences of third secondary grade's students at Kingdom of Bahrain. Psychological Studies, 5, 9-39.

51. Milloshi, M. (2013). How to improve the performance of high school education in the city of Durrës and to cultivate a more critical thinking at the students. 1st Albania International Conference On Education (AICE) (pp. 440-447) Tirana: Epoka University.

52. Montoya, L. (2007). Latina presidents in community colleges: a quantitative study of the elements of career advancement (Unpublished doctoral dissertation). New Mexico State University, Las Cruces, NM.

53. Moussa, N. (2003). Orientations and their relationship with cognitive methods and academic specialty of first secondary grade's students at El-Menia. Journal of Researches in Education and Psychology, 17(2), 158.

54. Nagy, K. (2008). Specialization of students choosing helping professions in partium (Unpublished doctoral dissertation). University of Debrecen, Debrecen.

55. Naseri, F., \& Ghabanchi, Z. (2014). The relationship between self-efficacy beliefs, locus of control and reading comprehension ability of Iranian EFL advance learners. International Journal of Language Learning and Applied Linguistics World, 5(1), 156-174. 
56. Nejabati, N. (2014). The effects of teaching self-regulated learning strategies and locus of control training on EFL students' reading comprehension. Proceedings of the Global Summit on Education GSE. 4-5 March, Kuala Lumpur: WorldConferences.net.

57. Nejati, M., Abedi, A., Aghaei, A., \& Mohammadi, M. (2012). The relationship between locus of control with the academic performance of the M.A. students by considering the role of life quality and satisfaction with life. Interdisciplinary Journal of Contemporary Research in Business, 4(5), 254-263.

58. Nikolaou, G. (2008). The university tutorial: Greek students' development of intercultural competences. Revista Interuniversitaria De Formación Del Profesorado, 22(1), 165-184.

59. Nuga, O. A. (2013). An exploration of the perceived academic self efficacy and locus of control of urban African American Students with learning disabilities (Unpublished doctoral dissertation). Wayne State University, Detroit, MI.

60. Oleg, Z., Eugene, P., Bogdan, V., Paweł, K., Wojciech, B., Marian, R., \& Zaborniak, S. (2011). The problem of professional awareness and legal culture of cadets-rescuers. Journal of Health Promotion and Recreation, 3 17-20.

61. Palade, A., \& Constantin, C. (2012). The necessity of counselling and vocational orientation in students' career management. Bulletin of the Transilvania University of Braşov, 5(2), 61-68.

62. Parameswari, J., \& Shamala, K. (2012). Academic motivation and locus of control among engineering students. Journal of Psychosocial Research, 7(1), 159-167.

63. Parker, G. R. (2011). Selected community leaders' perceptions of the role of the community college and the community college president in the community (Unpublished doctoral dissertation). North Carolina State University, Raleigh, NC.

64. Popova, S. (2012). Locus of control - predicators of health and subjective well-being. European Medical, Health and Pharmaceutical Journal, 4, 47-52.

65. Powell, C. R. (2004). Community college leadership in the new millennium: traits and characteristics of presidents of effective community colleges (Doctoral dissertation). Cleveland State University, Cleveland, $\mathrm{OH}$.

66. Rastegar, M., \& Heidari, N. (2013). The relationship between locus of control, test anxiety and religious orientation among Iranian EFL Students. Open Journal Of Modern Linguistics, 3(2), 108-113.

67. Rotter, J. (1966). Generalized Expectancies for Internal vs. External Control of Reinforcement. Psychological Mongraphs, 80(609).

68. Ryynänen, K. (2001). Constructing physician's professional identity-explorations of students' critical experiences in medical education (Doctoral dissertation). University of Oulu, Oulu.

69. Saadat, M., Ghasemzadeh, A., Karami, S., \& Soleimani, M. (2011). Relationship between self-esteem and locus of control in Iranian university students. Procedia - Social And Behavioral Sciences, 31, 530-535.

70. Sarıçam, H., Duran, A., \& Çardak, M. (2012). The examination of pre-school teacher candidates' academic locus of control levels according to gender and grade. Mevlana International Journal of Education, 2(2), 67-74.

71. Scaggs, S. L. (2004). The retention of black male students at Mississippi public community and junior colleges: identifying best practices in rural Mississippi community colleges (Unpublished doctoral dissertation). Mississippi State University, Mississippi State, MS.

72. Scolari, L. A. (2012). First-generation students of color: easing their transition to community college (Unpublished doctoral dissertation). San Francisco State University, San Francisco, CA.

73. Serin, N. B., Serin, O., \& Şahin, F. S. (2010). Factors affecting the locus of control of the university students. Procedia - Social and Behavioral Sciences, 2, 449-452.

74. Stocks, A., April, K. A., \& Lynton, N. (2012). Locus of control and subjective well-being - a cross-cultural study. Problems and Perspectives in Management, 10(1), 17-25.

75. Tella, A., Tella, A., \& Adeniyi, O. (2009). Locus of control, interest in schooling, self-efficacy and academic achievement. Cypriot Journal of Educational Sciences, 4, 168-182.

76. Terzi, A. R., Çetin, G., \& Eser, H. (2012). The relationship between undergraduate students' locus of control and epistemological beliefs. Educational Research, 3(1), 030-039.

77. Thomas, S. E. (2003). Community colleges and economic development: a case study of Appalachian Southwest Virginia (Unpublished doctoral dissertation). University of Virginia, Charlottesville, VA.

78. Uçar, T., \& Duy, B. (2013). The relationship between locus of control and self-confidence with problem solving skills of midwifery and nursing students. TAF Preventive Medicine Bulletin, 12(6), 689-698. 
79. Vickers, K. J. (2007). An assessment of leadership development programs for employees in Iowa's community colleges (Unpublished doctoral dissertation). Iowa State University, Ames, IA.

80. Wallace, M. T., Barry, C. T., Zeigler-Hill, V., \& Green, B. A. (2012). Locus of control as a contributing factor in the relation between self-perception and adolescent aggression. Aggressive Behavior, 38, 213221.

81. Ware, N. G. (2011). Ethics instruction in community college leadership programs: Southern perspectives (Unpublished doctoral dissertation). Mississippi State University, Mississippi State, MS.

82. Weltsch, M. D. (2009). A study of community college presidential qualifications and career paths (Unpublished doctoral dissertation). Kansas State University, Manhattan, KS.

83. Wiroterat, W. (2013). Dynamic audit knowledge and audit success of CPAs in Thailand: an empirical investigation of the antecedents and consequences. International Journal of Business Strategy, 1, 89-106.

84. Wyatt, D. A. (2009). Illinois community college presidents' perspectives of the all-comprehensive community college mission (Unpublished doctoral dissertation). Capella University (online).

85. Yarber, Jr., J. W. (2006). Computer technology skills - an analysis of perceptions from medium size employers and community college faculty in the Northeast Mississippi community college district (Unpublished doctoral dissertation). Mississippi State University, Mississippi State, MS.

86. Zaidi, I. H., \& Mohsin, M. N. (2011). Locus of control in graduation students. International Journal of Psychological Research, 6(1), 15-20.

87. Zhang, W., Liu, H., Jiang, X., Wu, D., \& Tian, Y. (2014). A longitudinal study of posttraumatic stress disorder symptoms and its relationship with coping skill and locus of control in adolescents after an earthquake in China. Post-Disaster Psychological Health in Adolescents, 9(2), 1-8. 